\title{
Kinematics of the Høybakken detachment zone and the Møre-Trøndelag Fault Complex, central Norway
}

\author{
P. T. OSMUNDSEN ${ }^{1}$, E. A. EIDE ${ }^{1}$, N. E. HAABESLAND ${ }^{2}$, D. ROBERTS ${ }^{1}$, T. B. ANDERSEN ${ }^{2}$, \\ M. KENDRICK ${ }^{1,3}$, B. BINGEN ${ }^{1}$, A. BRAATHEN ${ }^{4}$ \& T. F. REDFIELD ${ }^{1}$ \\ ${ }^{1}$ Geological Survey of Norway, 7491 Trondheim, Norway (e-mail: per.osmundsen@ngu.no) \\ ${ }^{2}$ Department of Geology, P.b. 1047, University of Oslo, 0316 Oslo, Norway \\ ${ }^{3}$ Present address: School of Earth Sciences, University of Melbourne, Melbourne, Vic. 3010, Australia \\ ${ }^{4}$ Centre of Integrated Petroleum Research (CIPR), University of Bergen, Allégaten 41, Bergen, Norway
}

\begin{abstract}
The tectonic disintegration of the Caledonian orogen through combined extension, contraction and strike-slip was characterized by spatial and temporal strain partitioning through a period of at least $30 \mathrm{Ma}$. Early to Mid-Devonian exhumation of the Central Norway basement window was associated with retrograde, top-to-the-SW extensional shearing in the Høybakken detachment zone, sinistral shearing along the MøreTrøndelag Fault Complex, and formation of extension-parallel folds. Progressive exhumation led to increasing strain localization and to the transition from ductile to brittle deformation. In the interval between $c .370$ and $320 \mathrm{Ma}$, the Høybakken detachment fault cut previously folded detachment mylonites, capturing mylonites in its hanging wall. ${ }^{40} \mathrm{Ar} /{ }^{39} \mathrm{Ar}$ mica and $\mathrm{K}$-feldspar ages indicate a Late Devonian or younger age for the uppermost parts of the adjacent 'Old Red' basin. Gentle folding of this stratigraphic level attests to the continuation of shortening and orogen-oblique extension into Late Devonian-Carboniferous time. Shortening was intensified along strands of the Møre-Trøndelag Fault Complex, as shown by mutually cross-cutting reverse and strike-slip faults. 'Flower structures' may be particularly common in constrictional strain systems where strike-slip faults develop parallel to the principal elongation trend, but normal to the principal axis of shortening.
\end{abstract}

The identification of constrictional strain patterns in metamorphic core complexes (e.g. Fletcher \& Bartley 1994) has led to a more $3 \mathrm{D}$ approach to large-magnitude extensional systems and, in particular, to extended orogens such as the Caledonides (e.g. Andersen et al. 1994; Chauvet \& Séranne 1994; Krabbendam \& Dewey 1998; Terry \& Robinson 2003). In this paper, we describe the relationships between extension, strike-slip and shortening structures in an area that occupies a key location in the extended remains of the Scandinavian Caledonides. In the outer Trondheim region of central Norway, the extensional Høybakken Detachment of Séranne (1992) terminates against the sinistral Hitra-Snåsa Fault of the Møre-Trøndelag Fault Complex. Both structures are thought to have played key roles in the post-orogenic disintegration of the Scandinavian Caledonides (Séranne 1992; Krabbendam \& Dewey 1998; Osmundsen et al. 1998; Braathen et al. 2000). The Høybakken detachment zone was fundamental in the exhumation history of the Central Norway basement window (Braathen et al. 2000), a regional gneiss dome that resembles a metamorphic core complex, and for the evolution of the 'Old Red' basins of the Trondheim area (Séranne 1992; Braathen et al. 2000). The Møre-Trøndelag Fault Complex has been interpreted as a sinistral strike-slip fault that originated as a transfer fault during Devonian exhumation and basin sedimentation (Séranne 1992; Braathen et al. 2000). Recent results from ${ }^{40} \mathrm{Ar} /{ }^{39} \mathrm{Ar}$ geochronology indicate that parts of the sedimentary succession in the outer Trondheim area are Late Devonian at the oldest (Eide et al. 2005). Thus, in the following, the sedimentary rocks in the hanging wall of the Høybakken detachment zone will be termed 'Old Red' rather than 'Devonian'. Below, we address the structural evolution of the Høybakken detachment zone and the adjacent Møre-Trønde- lag Fault Complex in the light of recent $\mathrm{U}-\mathrm{Pb}$ and ${ }^{40} \mathrm{Ar} /{ }^{39} \mathrm{Ar}$ geochronological data. We suggest that the rocks of the Central Norway basement window were exhumed in the footwall of the Høybakken detachment for a period of more than $30 \mathrm{Ma}$ and that exhumation was associated with a complex deformation and sedimentation history. We argue that extension-normal shortening was intensified in a belt adjacent to the Møre-Trøndelag Fault Complex, resulting in thrusting in a direction normal to the fault trend and development of positive flower structures. The strain evolution and sedimentation history presented below has implications for the late-stage evolution of the Scandinavian Caledonides, but may also serve as an analogue for large-magnitude extensional systems elsewhere.

\section{Geological setting}

The Scandinavian Caledonides formed in Late Silurian to Early Devonian times as a result of collision between Laurentia and Baltica in what is termed the Scandian orogeny (Gee 1975; Roberts \& Gale 1978; Stephens \& Gee 1985). Baltic basementcover slices as well as exotic terranes were thrust southeastwards across the Baltoscandian margin (e.g. Stephens \& Gee 1985) and, based on present-day stacking order, they are grouped in terms of Lower, Middle, Upper and Uppermost Allochthons (Fig. 1; Roberts \& Gee 1985). According to recent studies, emplacement of nappes onto Baltica was partly or largely completed around $415 \mathrm{Ma}$, prior to the $c .415-400 \mathrm{Ma}$ ultrahigh-pressure metamorphism of the Western Gneiss Region of western Norway (e.g. Terry et al. 2000; Tucker et al. 2004; Hacker \& Gans 2005; Root et al. 2005). In this last phase of the collision, however, both Baltic basement and a number of nappe units were buried to 

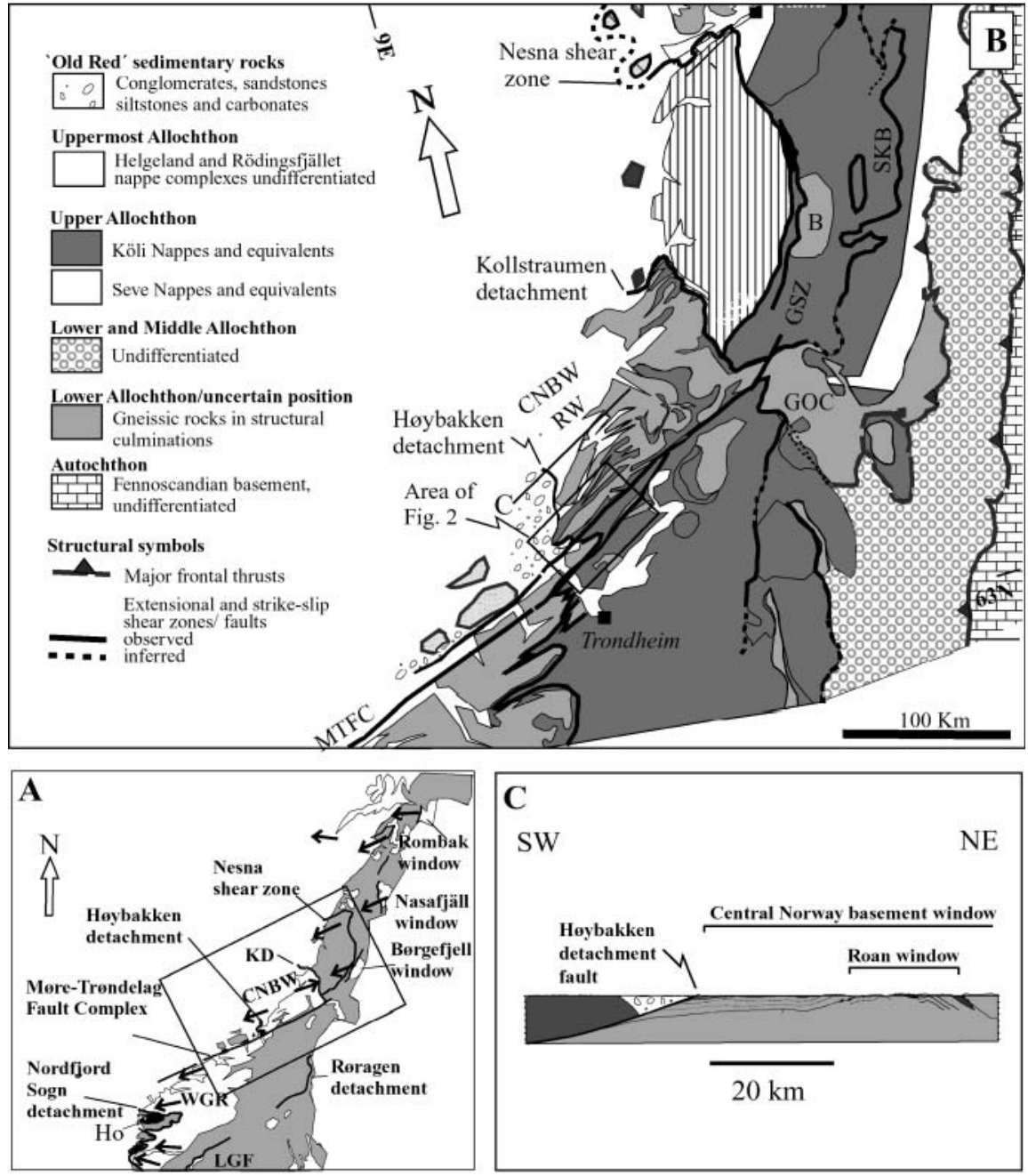

Fig. 1. (a) Simplified overview map of central Norway (modified from Braathen $e t$ al. 2002) with transport directions on Devono-Carboniferous extensional shear zones and detachments (open arrows). A noteworthy feature is the swing in orientation from top-to-the-west in SW Norway (sub-Jotun nappe shear zone and Nordfjord-Sogn detachment zone) to topto-the-SW along and to the north of the deformation belt that hosts the MøreTrøndelag Fault Complex (Fossen 1992; Chauvet \& Séranne 1994; Robinson 1995; Krabbendam \& Dewey 1998; Braathen et al. 2002; Osmundsen et al. 2003). CNBW, Central Norway basement window; Ho, Hornelen Basin (Devonian); KD, Kollstraumen detachment; LGF, LærdalGjende Fault; WGR, Western Gneiss Region. (b) Geological overview map showing distribution of gneiss-cored culminations, main Caledonian allochthonous units and location of extensional and strike-slip zones related to late to post-orogenic evolution of the Scandinavian Caledonides. Location of Figure 2 is shown. B, Børgefjell window; GOC, Grong-Olden Culmination; GSZ, Gaukarelv shear zone; RW, Roan window; SKB, Seve-Köli boundary. (c) Schematic cross-section traversing the Central Norway basement window, the Roan window, the Høybakken detachment fault and the 'Old Red' basin. Location shown in (b). depths of c. $125 \mathrm{~km}$, resulting in the formation of diamond- and coesite-bearing eclogites (Dobrzhinetskaya et al. 1995; Wain 1997). Burial and ultrahigh-pressure metamorphism was rapidly followed by substantial denudation (Terry et al. 2000; Terry \& Robinson 2003).

From the Early Devonian onwards, extensional shear zones dissected the Scandian nappe pile into a series of extensional allochthons that became juxtaposed with an elongate array of gneiss-cored culminations that resemble metamorphic core complexes (e.g. Norton 1986; Sjöström \& Bergman 1989; Séranne 1992; Braathen et al. 2000, 2002; Osmundsen et al. 2003, 2005). In SW Norway, the juxtaposition of Mid-Devonian sedimentary basins against the eclogite-bearing Western Gneiss Region across the Nordfjord-Sogn Detachment Zone (Fig. 1a) attests to extreme amounts of attenuation with bulk, top-to-the-west displacements of the order of 40-100 km (e.g. Hossack 1984; Norton 1986; Séranne \& Séguret 1987; Andersen \& Jamtveit 1990; Andersen et al. 1994; Fossen 1992; Fossen \& Dunlap 1998; Osmundsen et al. 1998).

North of the Møre-Trøndelag Fault Complex, amphibolitefacies Palaeoproterozoic orthogneisses, correlated with the Western Gneiss Region, crop out in the Central Norway basement window (Gilotti \& Hull 1993; Braathen et al. 2000) together with infolded supracrustal rocks (Fig. 1b). In the southwestern Central Norway basement window, close to the Møre-Trøndelag Fault Complex, infolded supracrustal rocks consist largely of strongly deformed, Ordovician granodioritic to dioritic rocks that also characterize parts of the Støren Nappe in the western Trondheim region (Solli et al. 1997). Other infolded metasediments have been assigned to the Seve Nappe of the Upper Allochthon (Solli et al. 1997). The supracrustal rocks generally reached kyanite metamorphic grade, and evidence for granulitefacies metamorphism has been reported from structurally deep parts of the Central Norway basement window in the Roan area (Møller 1988, Fig. 1b and c) and dated at c. $432 \mathrm{Ma}(\mathrm{Rb}-\mathrm{Sr}$ whole-rock age, Dallmeyer et al. 1992). The Central Norway basement window is folded into NE-SW-trending, upright folds that are subparallel to the Møre-Trøndelag Fault Complex and to a stretching lineation that is variably developed in the orthogneisses and supracrustal rocks (Piasecki \& Cliff 1988; Gilotti \& Hull 1993; Braathen et al. 2000). In the NE, the Central Norway basement window is flanked by the top-to-theENE Kollstraumen detachment, which juxtaposes the Central Norway basement window with rocks of the Upper and Uppermost Allochthons (Braathen et al. 2000; Nordgulen et al. 2002). In the SW, the Høybakken detachment zone juxtaposes the Central Norway basement window against rocks of the Upper and Uppermost Allochthons and against low-grade to nonmetamorphic 'Old Red' sedimentary rocks of the Bjugn-Ørlandet and Asenøy-Tristeinen basins (Fig. 2). A hanging-wall assemblage of 'Old Red' basin rocks, Ordovician plutonic rocks and associated metasediments of the Upper and Uppermost 

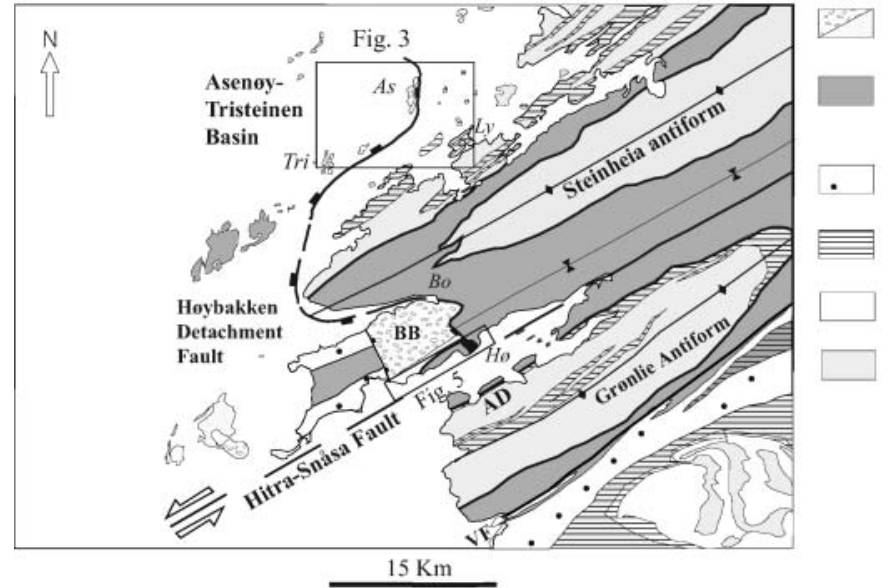

'Old Red' conglomerates and sandstones

Intrusive rocks in the Upper Allochthon

Metasedimentary rocks, Köli equivalents

Seve Nappe equivalents?

Metasedimentary rocks in Lower/Middle Allochthon Gneisses (mainly granitic orthogneisses) of the Central Norway basement window and the Western Gneiss Region
Fig. 2. Geological map of study area with outlined areas of detailed maps shown in Figures 3 and 5. The brittle Høybakken detachment fault truncates the pattern of regional syn- and antiforms that deform the rocks of the Central Norway basement window as well as extensional mylonites. $\mathrm{AD}$, Agdenes detachment of Robinson et al. (2004); BB, Bjugn-Ørlandet Basin; VF, Verran Fault; As, Asenøy; Bo, Botngård; Hø, Høybakken; Ly, Lysøysund; Tri, Tristeinen. Tectonostratigraphy follows that of Solli et al. (1997) and Tucker et al. (2004).
Allochthons has been mapped southwestwards to the Kristiansund area (e.g. Siedlecka \& Siedlecki 1972; Bryhni 1974; Askvik \& Rokoengen 1985; Bøe 1989; Bøe et al. 1989; Tucker et al. 2004). Based on sparse floral and faunal assemblages, the 'Old Red' basin remnants of the outer Trondheim region have been interpreted as Early to Mid-Devonian in age (Siedlecka 1975; Allen 1976; Séranne 1992).

According to previous models for western Norway (Chauvet \& Séranne 1994; Krabbendam \& Dewey 1998; Osmundsen et al. 1998; Osmundsen \& Andersen 2001; Dewey \& Strachan 2003), sinistral strike-slip deformation in the area of the MøreTrøndelag Fault Complex during the Devonian resulted from megascale transtensional deformation of the Caledonides. This is partly evident from the trend of Devonian stretching lineations (Fig. 1), which changes from WNW-ESE to NE-SW in the northern parts of the Western Gneiss Region (Chauvet \& Séranne 1994; Krabbendam \& Dewey 1998). The Møre-Trøndelag Fault Complex is part of a NE-SW-trending deformation belt that is characterized by extreme ductile attenuation of Caledonian nappe units, but also by folding and imbrication, that can be traced northeastwards to the Grong-Olden Culmination (Fig. 1; Grønlie \& Roberts 1989; Robinson 1995; Watts 2001; Terry \& Robinson 2003, 2004). In SW Norway, Scandian eclogites occur in the Lindås nappe in the Bergen area (Bingen et al. 2004; Jolivet et al. 2005). In the northern Western Gneiss Region, however, part of the thrusting appears to post-date high- and ultrahigh-pressure metamorphism in the Western Gneiss Region around 402$407 \mathrm{Ma}$ (Terry et al. 2000; Terry \& Robinson 2003; Hacker \& Gans 2005).

\section{The Hoybakken detachment zone}

The Høybakken detachment zone as defined in this paper comprises a ductilely deformed footwall that includes the Central Norway basement window with its carapace of infolded nappe units and detachment mylonites, a brittle detachment fault (Høybakken detachment fault) with a variety of fault products, and structurally low parts of the hanging wall, hosting both ductile and brittle deformation products. We now describe the detachment zone from low to structurally high levels, and then describe the fault strands related to the Møre-Trøndelag Fault Complex in the study area.

\section{The footwall}

Medium-grade $L \geqslant S$ tectonites. At a level c. $2.5 \mathrm{~km}$ structurally below and c. $8 \mathrm{~km}$ east of the Høybakken detachment fault, the orthogneisses of the southwestern Central Norway basement window are deformed into $\mathrm{L}>\mathrm{S}$ tectonites with little evidence for non-coaxial deformation. Stretching of amphibolite dykes and granite pegmatites into prolate shapes is commonly observed in the orthogneisses. Infolded, garnet-kyanite-bearing paragneisses are commonly migmatitic, with leucosomes that are mostly concordant with the main foliation. East-west- to NESW-trending folds deform the migmatitic gneisses, providing evidence that migmatization largely predated, or was coeval with folding. A $\mathrm{U}-\mathrm{Pb}$ monazite age of $426 \pm 1 \mathrm{Ma}$ was obtained from a leucosome in a kyanite-garnet-bearing paragneiss and is thought to date migmatization (Bingen et al. 2003, 2005). At higher structural levels, sheets of gneiss with relict $L \geqslant S$ fabrics can sometimes be recognized in the detachment mylonites. For instance, a kyanite-grade, amphibolite-facies $\mathrm{L} \geqslant \mathrm{S}$ fabric is preserved in a rootless, kilometre-long sliver of paragneiss contained within the mylonites of the main detachment zone (Fig. 3). Within this sheet, garnet porphyroclast tails and centimetres-long kyanite crystals define a strong, ENE-WSWtrending mineral lineation parallel to that in the surrounding detachment mylonites. Towards its margins, the sliver of paragneiss becomes more intensively foliated and is cut by retrograde shear bands.

Detachment mylonites. Towards the Høybakken detachment fault, a biotite- to chlorite-grade, protomylonitic to mylonitic fabric becomes progressively developed, particularly in the infolded tongues of paragneisses and schists. The detachment mylonites have diverse protoliths; in the Botngård-Høybakken area, metadioritic lithologies assigned to the Køli Nappes dominate, whereas east of Asenøy, paragneisses and marbles, correlated with the Seve Nappe (Séranne 1992; Solli et al. 1997; Tucker et al. 2004), are commonly present in the mylonite succession.

NW of the Bjugn basin east of Botngård (Fig. 2), the rock is principally a biotitic, protomylonitic LS tectonite. The foliation has a shallow southeasterly dip and a subhorizontal, NE-SWtrending mineral lineation defined by amphibole, biotite and feldspar. Adjacent to the detachment fault at Høybakken, the metadioritic rocks are more strongly mylonitized and characterized by densely spaced shear bands with a biotite and/or chlorite 


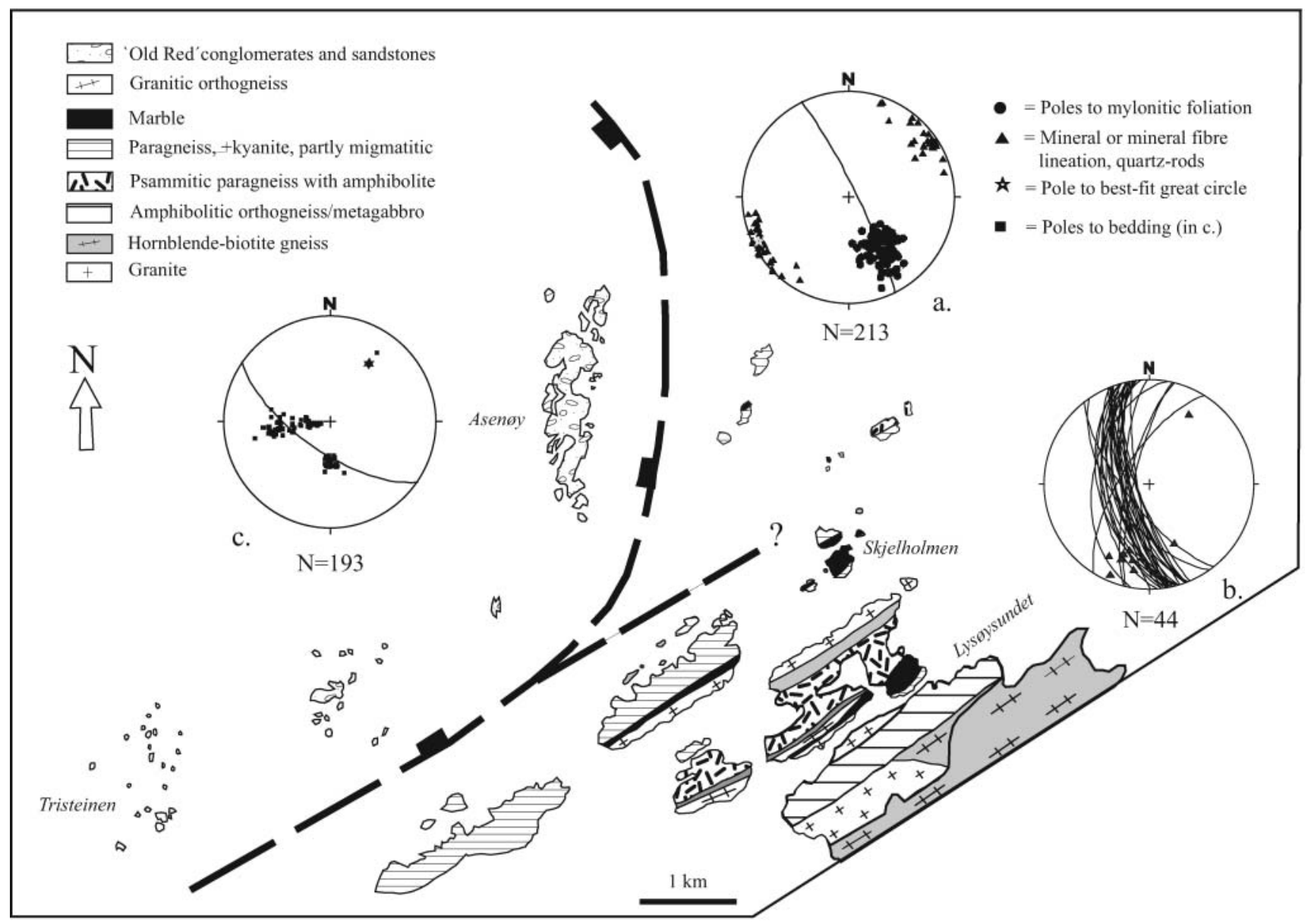

Fig. 3. Geological map of the Lysøysund-Asenøy area with inferred trace of the Høybakken detachment fault east of the Asenøy Basin (Haabesland 2002). Within the map area, many of the rocks in the footwall are affected by rotational deformation related to top-to-the-SW shearing. Stereograms present the following data. (a) Kinematic data recorded in the footwall of the Høybakken detachment fault east of Asenøy. Pole to best-fit great circle for the main foliation (star) is oriented at 244/07 and is parallel to a number of outcrop-scale, lineation-parallel folds. (b) Oblique, normal-sinistral faults and shear fractures (great circles) that cut mylonitic fabrics. Lineations plunge more southerly than the ductile stretching lineation, probably reflecting some rotation by folding after faulting. (c) Equal-area stereographic representation of bedding in the Asen Formation, Asenøy. Pole to best-fit great circle at 035/22. The NE plunge of the fold axis probably reflects folding of bedding with a dip towards the basin-controlling detachment fault.

mineralogy and a pronounced, SW-plunging mineral (biotite, chlorite and quartz-rod) lineation. The amount of chlorite in the mylonites increases upwards, until virtually all biotite is replaced by chlorite. Immediately below the brittle detachment fault, a greyish-white, silicified, chlorite-bearing mylonite sheet occurs (Séranne 1992). Locally, east of the trace of the brittle detachment fault, the white mylonite sheet has a thickness of several metres, and the mylonitic foliation dips to the NE (i.e. opposite to the dip direction of the detachment fault) and the stretching lineation is correspondingly NE-plunging.

Immediately east and south of the Asenøy basin (Fig. 3), the footwall comprises a suite of metasupracrustal rocks with biotite-chlorite-garnet-bearing mylonites, phlogopite-bearing marbles, and the garnet-kyanite-staurolite-bearing paragneisses described above. The mylonites contain a strongly developed, shallow WSW-plunging mineral and quartz-rod lineation, sheared quartz veins, and abundant kinematic indicators such as rotated garnet porphyroclasts and mineral aggregates such as amphibole \pm quartz and epidote, foliation 'fish' and shear bands that indicate down-plunge, top-to-the-WSW transport along the mineral lineation (Fig. 3a and b).

The supracrustal rocks contain numerous granite dykes that range from cross-cutting to completely concordant with respect to the main foliation. Some of the granites contain a well-developed foliation subparallel to the main foliation in the host rock, whereas others are pegmatitic and practically unfoliated. In sections normal to the stretching lineation, dykes commonly cut the main foliation, and locally, stretched and boudinaged granite dykes are observed to cut NE-SW-trending quartz rods and folds in sections parallel to the stretching lineation. In a thick marble succession exposed at Skjelholmen (Fig. 3), granitic dykes form spectacular strain markers in an otherwise recrystallized marble matrix. The granite dykes are deformed into lineation-parallel, asymmetric folds and fold mullions, which are commonly cut by normal to oblique, small-scale faults trending at a high angle to the mineral lineation, that are not present in the adjacent marbles (Fig. 4a). Other examples of brittle, 'intrafolial' faults are found along the base of the marble succession at Skjelholmen as well as at structurally lower levels, where layers of banded gneiss are deformed into asymmetric, fault-block arrays between layers of amphibolite (Fig. 4b). Whereas the gneissic foliation displays an ENE-WSW-trending mineral lineation, the lineation on the mesoscopic faults is commonly oblique with a more southerly plunge (Fig. 3b). 

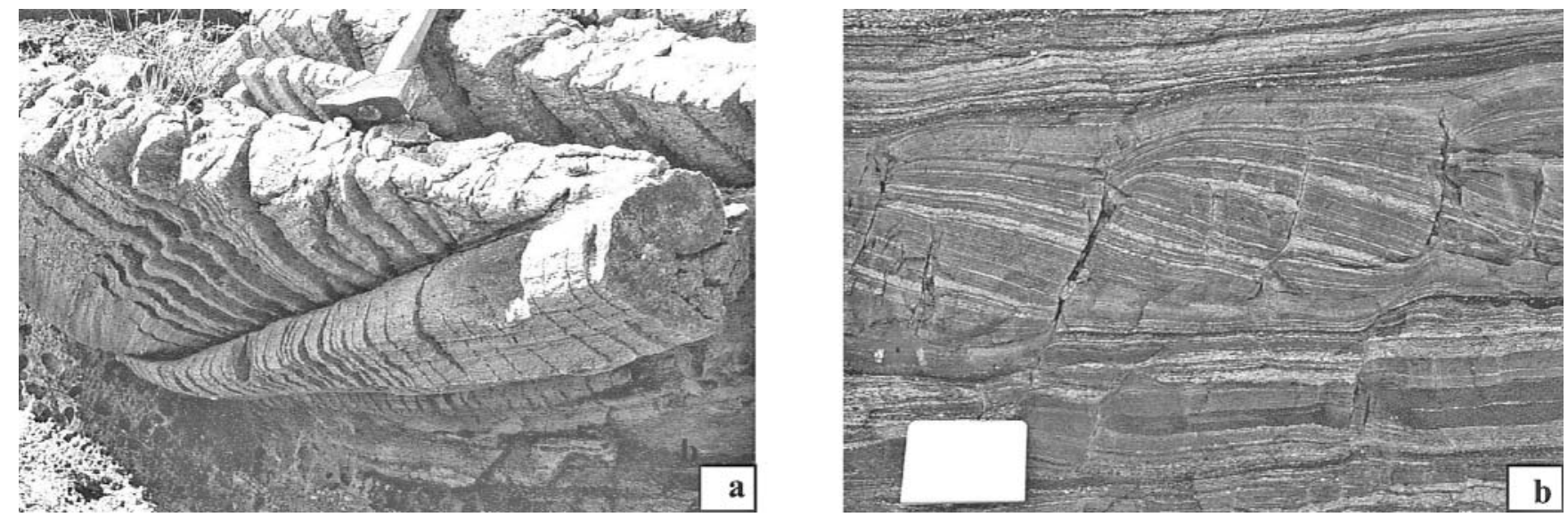

Fig. 4. (a) Granite dyke as a strain marker in marble at Skjelholmen. The dyke is deformed into SW-plunging mullions that are cut by later, small-scale normal faults at a high angle to the ductile stretching lineation. Hammer for scale. (b) Intrafolial shears and array of rotated, asymmetric boudins in banded gneiss, island NE of Lysøysund. The shear fractures display southerly plunging lineations (see Fig. 3b).

Folds. The entire structural section is deformed by a set of open to tight, double-plunging, NE-SW-trending folds with upright to NW-dipping axial planes. Folds of this type are numerous on the outcrop as well as at map scale. On the regional scale, these folds deform the entire Central Norway basement window in the area between the Høybakken and Kollstraumen detachments (Roberts 1983; Piasecki \& Cliff 1988; Gilotti \& Hull 1993; Braathen et al. 2000; Nordgulen et al. 2002), and the axes of mesoscopic folds commonly contribute to the ' $\mathrm{L}$-element of the LS-fabrics in the window, including the detachment mylonites. NE-SW-trending folds also deform the 'Old Red' basins above the Høybakken detachment zone (Fig. 3c; Séranne 1992, and below).

\section{The Høybakken detachment fault}

On the regional scale, the Høybakken detachment fault or system of detachment faults truncates the boundaries between nappe rocks that are infolded with the orthogneisses of the Central Norway basement window (Fig. 2). Map-scale undulations of the Høybakken detachment fault do, however, partly follow the pattern of NE-SW-trending folds in the footwall (Séranne 1992). East of Asenøy, a (submerged) detachment fault has been interpreted to constitute the eastern border of the Old Red Asenøy-Tristeinen basin (Figs 2 and 4; Séranne 1992; Haabesland 2002). At the type locality at Høybakken, the detachment fault cuts folded, mylonitized diorite in its footwall (Fig. 5). The footwall mylonites are juxtaposed against the strongly deformed meta-igneous rocks of the Borgklintan unit, notably the Eidsfjellet granite of Séranne (1992), whereas northwards, the hanging wall is dominated by the sedimentary rocks of the 'Old Red' Bjugn basin. In the uppermost c. $10 \mathrm{~m}$ of the footwall at Høybakken, coherent mylonites are variably fractured and shattered. Rock fragments in the shattered mylonites comprise mainly mylonitic diorite. In places, the top of the footwall is constituted of a greenish grey cataclasite developed from the footwall mylonites (Fig. 6).

At the main exposure in Høybakken, the detachment fault appears as a sharply defined fault plane that displays outcropscale undulations or corrugations that plunge southwestwards at an angle of $10-20^{\circ}$ (Fig. 5a). A NW-SE-trending slickenside and mineral fibre lineation is superimposed on the corrugations, and is interpreted here to represent a later deformation event.
The lowermost c. $0.5 \mathrm{~m}$ of the hanging wall is characterized by a zone of banded, red and grey-black cataclasites and ultracataclasites, and by a $c .25 \mathrm{~cm}$ thick, brown cataclasite that occurs intermittently along the fault plane (Fig. 6). The banded cataclasites contain fragments of mylonite and of a dark, finegrained cataclastic rock set in a matrix of comminuted quartz and feldspar. Higher up, the banded cataclasite is superseded by a red, more homogeneous cataclastic rock sandwiched between the main detachment and a structurally higher normal fault (Fig. 5). The cataclasite probably developed from the Eidsfjellet granite. The red cataclasite is cut by numerous narrow highstrain zones and striated mesoscopic faults. Many of the faults carry thin, greenish-grey quartz and/or epidote mineralizations or millimetre-thick zones of intense cataclasis. Slip-linear analysis (Fig. 5c and d) yields a SW-NE elongation trend that is consistent with the kinematics of ductile structures in the footwall as well as with the SW-plunging grooves and undulations on the detachment fault. A suite of small-scale faults with NW- to NNW-plunging slickenlines cut and displace the detachment fault on a scale of a few centimetres and may have been associated with the late movements recorded by the NW-SEtrending lineation on the detachment fault (Fig. 5b).

\section{The hanging wall}

Ductile, top-to-the-WSW non-coaxial deformation. At Høybakken, the Eidsfjellet granite and the Borgklintan Formation of Siedlecka (1975) (Fig. 5; Séranne 1992) occur in the hanging wall of the Høybakken detachment fault. The status of the Borgklintan Formation is important with respect to the overall structural interpretation, and needs some clarification. Séranne (1992) suggested that the Borgklintan Formation may represent mylonitized Devonian rocks. We prefer to uphold previous interpretations of the Borgklintan Formation as sheared metaigneous rocks (mainly metadiorite; Wolff 1976; Bergfjord 1989; Solli 1995; Solli et al. 1997); remnant lenses and smaller pods of less deformed metadiorite occur locally within the mylonitized host rock, and the association of sheared metadiorite-greenschist with minor amounts of metasediments strongly resembles rock units in the Upper Allochthon in the greater Trondheim area. Consistent with this interpretation, we will use the informal term 'Borgklintan unit' in the remaining parts of this paper.

The rocks of the Borgklintan unit are penetratively myloni- 

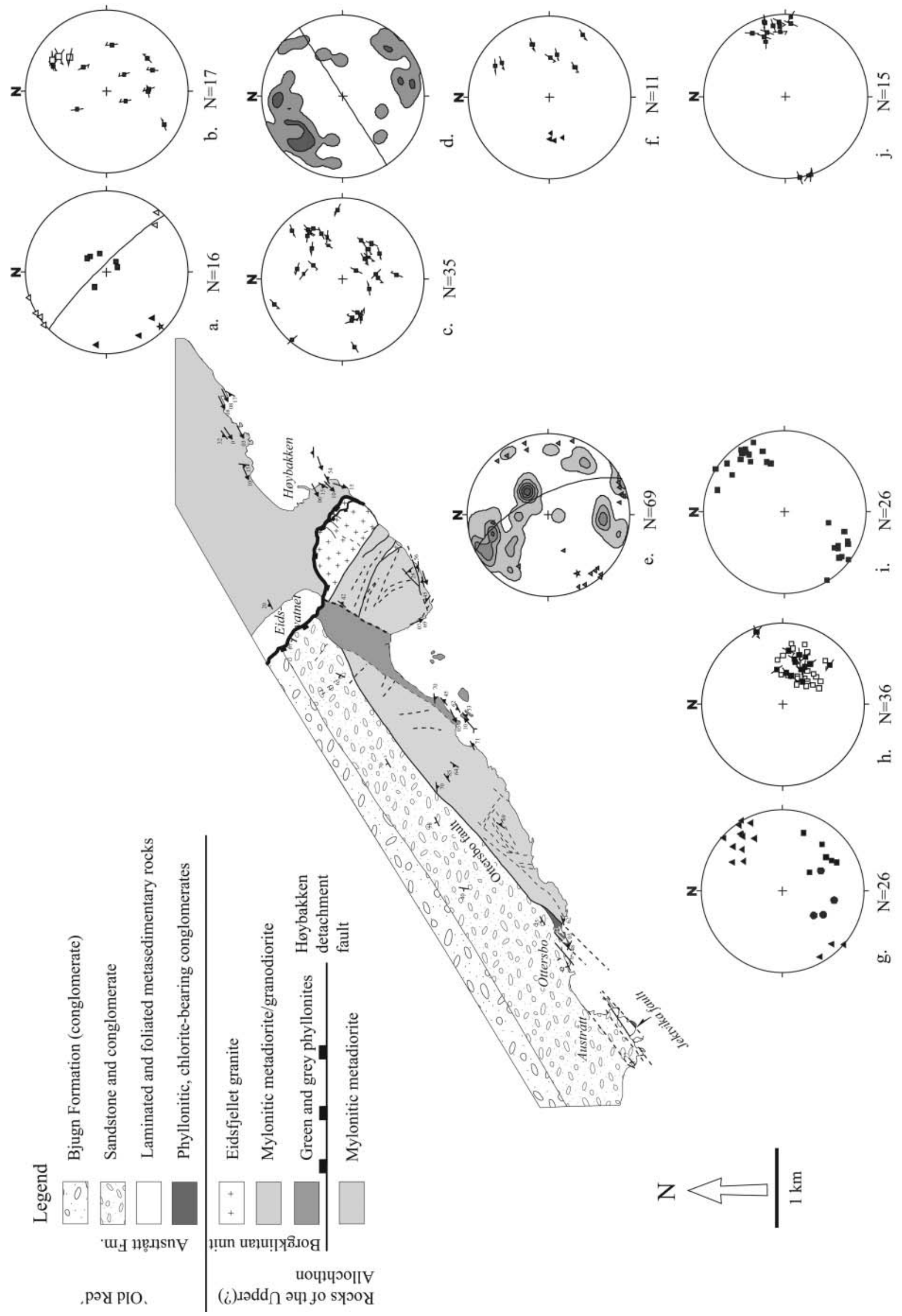
tized. Along the SE coast of the study area (Fig. 5), the Borgklintan unit contains a quartz-rod and chlorite mineral lineation and densely spaced shear bands consistent with top-tothe-SW shearing. Away from the brittle detachment, however, a ductile strain gradient characterizes the Borgklintan unit as the mineral and quartz-rod lineation is rotated from an ENE-WSW into a NNW-SSE trend in accordance with the undulating foliation pattern (Fig. 5e). Lithologically and, in part, structurally, the Borgklintan unit bears a striking resemblance to the rocks in the footwall of the brittle detachment. Further implications will be discussed below.

The Borgklintan unit is cut by a NE-SW-trending fault that separates it from the Austrått Formation, named here the Ottersbo fault. Close to the fault, at Ottersbo, conglomerate clasts in the lower parts of the Austraitt Formation are flattened subparallel to an undulating, low-grade phyllitic foliation. The phyllitic foliation is associated with an ENE-WSW-trending, low-grade (epidote \pm chlorite \pm quartz) mineral fibre lineation (Fig. 5g). This lineation is also present on a number of ductile and semi-ductile shear zones and faults that cut the main foliation and that border sigmoidal foliation 'fish' of small-scale to outcrop size, indicating normal-sinistral, top-to-the-WSW shear. The conglomerates are deformed into sets of open folds that have axes parallel to the mineral fibre lineation and are, in turn, cut by several sets of steep, brittle faults and joints oriented obliquely or at high angles to the stretching lineation. Some display NW-plunging quartz-fibre lineations that can be demonstrated to overgrow the previous chlorite fibre lineation (Fig. 5h). One set of small joints, oriented perpendicular to the stretching lineation, is associated with orange zeolite mineralization (Fig. 5i). The mineralized joints are, in places, offset by $1-5 \mathrm{~mm}$ by shear planes that are parallel to the low-grade mineral lineation.

The above observations demonstrate that top-to-the-SW ductile strains, kinematically consistent with those observed in the footwall, affected the southeastern parts of the hanging wall prior to brittle deformation. The interpretation of the Borgklintan unit as a sequence of deformed and metamorphosed plutonic rocks (Bergfjord 1989; Solli 1995) is consistent with the Høybakken detachment fault having developed at a relatively late stage compared with the ductile, top-to-the-SW deformation in the footwall and hanging wall.

Ductile to brittle, normal and oblique faults. SW of Høybakken, the mylonitic rocks of the Borgklintan unit, as well as the lower parts of the Austrått Formation, are cut by swarms of NE-SWto north-south-trending, normal-sinistral, semi-brittle to brittle mesoscopic faults and by densely spaced, open fractures (Fig. 6).

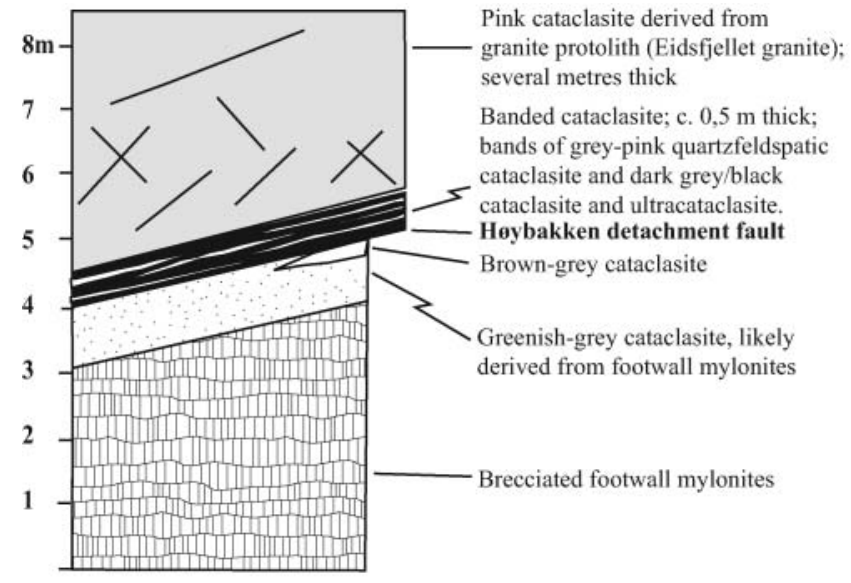

Fig. 6. Simplified, synthetic line drawing showing succession of fault products associated with the Høybakken detachment fault at Høybakken. A brownish, c. $20 \mathrm{~cm}$ thick cataclasite-breccia separates brecciated footwall mylonites from the cataclasites of the hanging wall; structurally higher, in the hanging wall, are banded cataclasites with pink and dark grey layers $(20-50 \mathrm{~cm}$ thick). The lowermost $c .5 \mathrm{~cm}$ of hanging wall is composed by dark cataclasite and ultracataclasite. Below the brown cataclasite are grey-green cataclasites that constitute the top of the footwall and are gradational downwards into cataclasites and breccias derived from the mylonitic metadiorite in the footwall.

Many of the faults and joints are associated with epidote mineralization and epidote-indurated breccias; others are associated with thin coatings of carbonate and/or orange zeolite. Where age relationships can be assessed, the latter two mineralizations are consistently younger than epidote-bearing mineralizations. The kinematic indicators associated with the faults are mainly in accordance with top-to-the-WSW and -SW faulting (Fig. 5) but locally, NW-plunging lineations are observed to overprint earlier, top-to-the-SW slickenfibres.

Some tens of metres structurally above the Høybakken detachment fault, a large normal to oblique fault is characterized by epidote-bearing mineralization and green cataclasites that host WSW-plunging grooves and slickenlines (Fig. 5f). The fault probably constitutes a large, intra-hanging-wall normal fault kinematically compatible with the main detachment fault.

NW-SE-trending fractures largely dominate the lineament pattern north of the Møre-Trøndelag Fault Complex (Rindstad \& Grønlie 1986; Grønlie et al. 1991; Gabrielsen et al. 2002) and are common in the study area, where they cut all previous

Fig. 5. Map of Høybakken-Austrått area with the Høybakken detachment fault and NE-SW-trending strands of the Møre-Trøndelag Fault Complex described in the text. (a) Stereographic Schmidt-net representation of observations from the Høybakken detachment fault, including undulating fault plane (घ) with pole to best-fit great circle (star), yielding roughly the orientation of a local large-scale corrugation axis (trend $c .225^{\circ}$ ), measured megagrooves $(\mathbf{\Lambda})$, and younger mineral fibre and slickenside lineation $(\triangle)$. (b) Slip-linear plot of small-scale faults that cut the Høybakken detachment fault; a larger fault that cuts and offsets the detachment fault and footwall mylonites is represented by three readings (larger squares). (c) Slip-linear plot of mesoscale faults that cut red cataclasite in the hanging wall of the Høybakken detachment fault fault. (d) Poles to 'planes of movement' (m-planes, Alexandrowski, 1985) calculated from fault population in (c), the mean m-plane (great circle) indicates movement of the hanging wall towards $c$. $237^{\circ}$. (e) Slip-linear representation of fault planes with epidote-mineralized segments and splays associated with large fault structurally above the detachment fault; $\boldsymbol{\Lambda}$, larger corrugations on this fault plane. (f) Ductile structures in the Borgklintan unit including (mylonitic) main foliation (contoured); pole to best-fit great-circle for deflected main foliation (star, 244/21), mineral and quartz-rod stretching lineation (ム). (g) Ductile structures in the Lowermost Austrått Fm at Ottersbo, including main (phyllonite) foliation $(\bullet)$; mineral fibre (chlorite, quartz) stretching lineation $(\mathbf{\Delta})$ and ductile shear bands $(\mathbf{\square})$. (h) Ductile-tobrittle, normal-sinistral faults in the lower Austrått Fm at Ottersbo. Slip-linear representation of striated faults, poles to faults without striae are represented by open squares. (i) Zeolite-filled tension gashes, Ottersbo. These fractures cut ductile and semi-ductile structures such as those in (g) and (h) above. However, they are consistent with a NE-SW-oriented maximum elongation trend. (j) Slip-line representation of north-south- to NE-SW-trending, steep faults. The slipline orientations range from NE-SW to NW-SE. 
structures, and bound a basement horst that crops out in the central areas of the Bjugn Basin. At Høybakken, a NW-SEstriking fault, containing epidote-bearing mineralization and green cataclasites and hosting WNW-plunging lineations (Fig. $5 b$ ), demonstrably cuts the Høybakken detachment fault and produces a shatter zone of several metres width in the detachment mylonites. Kinematic data from a number of steep, NNWSSE- to NW-SE-trending fractures (Fig. 5j) are consistent with more than one slip event, as several fault zones display down-dip as well as oblique, north-south- or NNE-SSW-trending slickenlines. The steeper lineations are in accordance with ENEWSW to WNW-ESE maximum elongation trends, as are intraclast tension gashes reported from the 'Old Red' conglomerates by Séranne (1992). In the Ottersbo area, NW-SE-trending tension gashes filled with orange zeolite are in places offset by small-scale shears developed parallel to the low-grade main foliation, indicating that, at least locally, zeolite mineralization commenced during NE-SW extension.

Structures related to NW-SE shortening. ENE-WSW-trending, upright folds deform the rocks of the 'Old Red' basins on the kilometre scale (e.g. Bøe et al. 1989; Fig. 3). Adjacent to strands of the Møre-Trøndelag Fault Complex, however, brittle contractional structures locally dominate the deformation pattern.

In the Austrått-Ottersbo area (Fig. 5), the lower parts of the Austrått Formation are telescoped by a suite of brittle thrusts and reverse faults ranging in dip from subhorizontal to $c .50^{\circ}$ to the SE (Figs 7a, b and 8). Kinematic indicators on the fault planes include grooves and striations, mineral fibre lineation, lineationparallel corrugations, displacement or semi-brittle folding of bedding and subordinate, mesoscopic normal faults and joints. The interpreted transport direction is consistently top-to-the-NW at c. $320^{\circ}$ (Fig. 7e and f). The contractional system involves subordinate extensional faults and steep, WSW-ESE- to NWSE-oriented strike-slip faults interpreted here as transfer faults (Fig. 7b). The thrust system is associated with cataclasis in the metasediments in the lowermost Austrått Formation and with epidote mineralization or silicification depending on location with respect to the strands of the Møre-Trøndelag Fault Complex (Fig. 8). Locally, dark, flinty fault rocks interpreted as pseudotachylite or ultracataclasite occur on the fault planes. The majority of contractional structures in this system are cut by, or merge with, the set of NE-SW-trending strands of the MøreTrøndelag Fault Complex. Intriguingly, however, small-scale structures of the contractional system also affect fault rocks related to strands of the Møre-Trøndelag Fault Complex (see below).

\section{Strands of the Møre-Trøndelag Fault Complex}

The southern parts of the study area are straddled by (seawatercovered parts of) the NE-SW-trending Hitra-Snåsa Fault, one of the principal faults of the Møre-Trøndelag Fault Complex (e.g. Grønlie \& Roberts 1989). Abundant strands or splays of the Møre-Trøndelag Fault Complex, probably belonging to the damage zone of the Hitra-Snåsa Fault, commonly define lithological boundaries, such as the Ottersbo fault, and boundaries between subunits in the Austrått Formation (Figs 5 and 8). The faults are associated with epidote mineralization, green to grey cataclasites and/or metres-wide shatter zones with striated fault planes. Subhorizontal grooves, locally on the metre scale, locally decorate the more prominent fault planes. The strands of the Møre-Trøndelag Fault Complex show mutual cross-cutting relationships with the Høybakken detachment fault in the
Høybakken area. On the larger scale, however, the Høybakken detachment fault is interpreted to terminate against the HitraSnåsa Fault (Séranne 1992).

In the study area, two of the more important NE-SW-trending faults are the Ottersbo and Jektvika faults near Austrått (Fig. 5). Ductile-to-brittle deformation of the Austraitt Formation is evident in a NE-SW-trending belt of several tens of metres width adjacent to the Ottersbo fault. In the Austrått Formation, detrital plagioclase becomes increasingly saussuritized in the direction of the fault, in concert with an increasing content of epidote, carbonate and chlorite in the matrix, and of epidote and carbonate in cross-cutting veins. In the Borgklintan unit, subvertical zones of granulation, semi-brittle kink folding and grey, flinty cataclasites up to several centimetres thick are commonly observed in the zone of cataclasis and fracturing of c. $50 \mathrm{~m}$ width associated with the Ottersbo fault. The Jektvika fault (Figs 6 and 8) is subvertical to steeply SE-dipping, and associated with a zone of epidote-bearing cataclasite of several metres width on both sides of the fault. A discrete, c. $50-75 \mathrm{~cm}$ thick, multilayered sheet of cataclasite (Fig. 7c) cuts the wider zone of cataclasis, but is, in turn, incised at a low angle by the main fault plane (Fig. 7d). The latter is coated by a centimetre-thick cataclasite that displays evidence for both dip-slip and oblique slip. Oblique sinistral shears, left-stepping of the main fault plane and quartz-filled tension gash arrays provide evidence for sinistral movements. This considered, oblique, SW-plunging lineations on the outermost cataclasite sheet are consistent with oblique sinistral displacement with a moderate reverse component.

With the exception of the outermost cataclasite sheet, the multilayered fault-rock succession is cut and displaced northwestwards by small-scale thrusts (Fig. 7c and d) with displacements up to c. $20 \mathrm{~cm}$ up-dip along a SE-plunging slickenside lineation. The direction of thrusting is similar to that obtained from the numerous thrusts and reverse faults recorded on the northwestern side of the fault. In our dataset recorded from a multitude of NE-SW-trending faults in the study area (Fig. 7g) slip-lines cluster in orientations parallel and normal to the fault trends. This is consistent with combinations of sinistral strikeslip movements and top-to-the-NW thrusting, such as interpreted for the Jektvika fault. Later structures, such as subordinate open fractures, provide indication of late movements with a dextral component along some NE-SW-trending faults and of minor reactivation of some reverse faults as normal faults. These features, together with some of the steep and oblique lineations, may represent post-Palaeozoic reactivation (Grønlie \& Roberts 1989; Bering 1992) such as that responsible for the formation of Jurassic basins adjacent to the Møre-Trøndelag Fault Complex in the Trondheimsfjord and coastal areas (Bøe \& Bjerklie 1989; Bøe 1991; Sommaruga \& Bøe 2002; Watts 2001), or Cenozoic movements (Redfield et al. 2005).

\section{Discussion}

\section{Ductile, large-magnitude extension and constriction in Mid-Norway}

In the entire western and Mid-Norway region, the Devonian strain field responsible for this deformation was probably bulk constrictional, to produce the well-developed $\mathrm{L} \geqslant \mathrm{S}$ tectonites, mylonites and folds that are, in turn, decapitated by brittle detachment fault(s). This would indicate that constrictional deformation accompanied the continued exhumation of the 

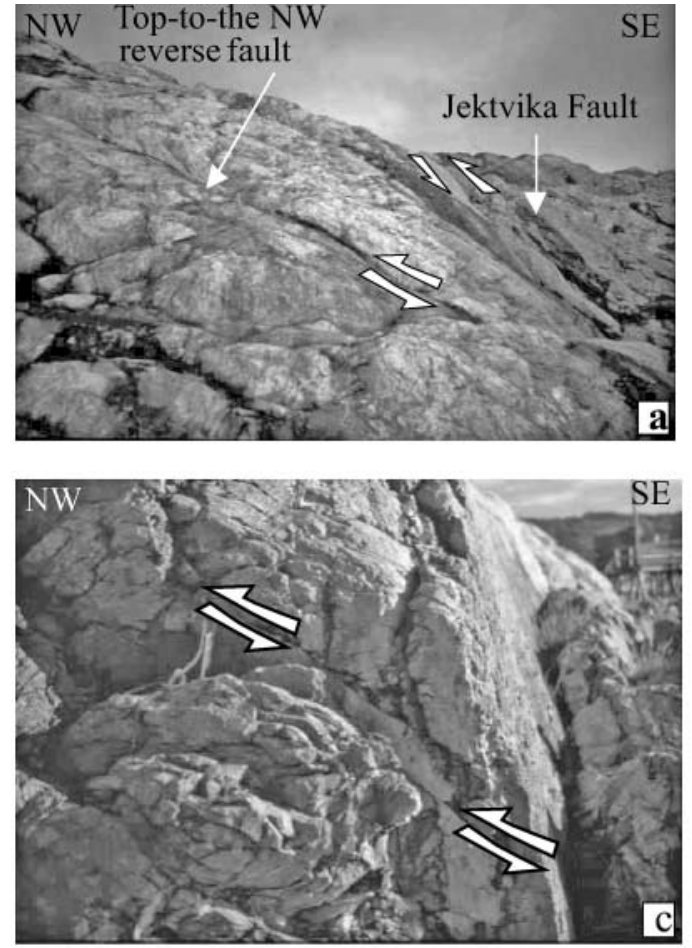

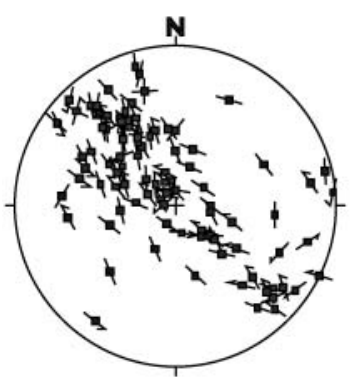

e. $\quad \mathrm{N}=99$

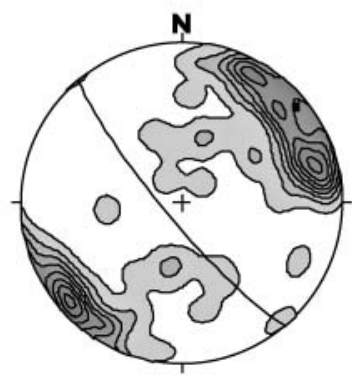

f.

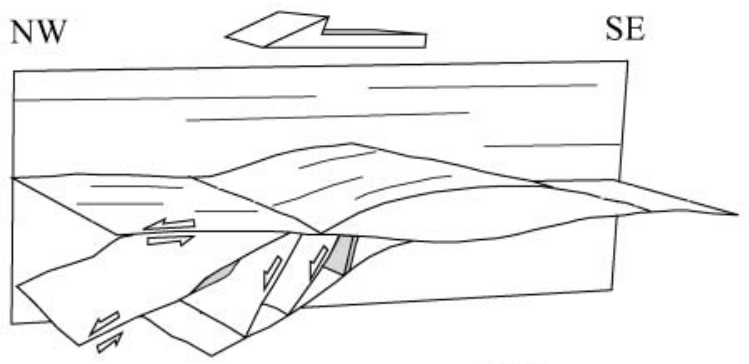

b.

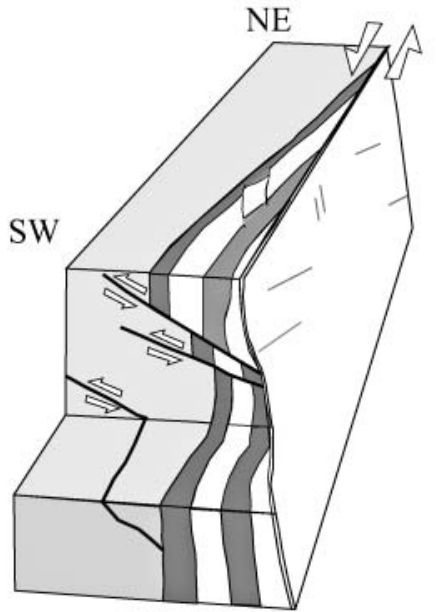

d.

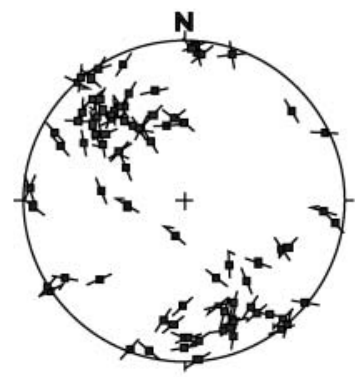

g. $\quad \mathrm{N}=92$

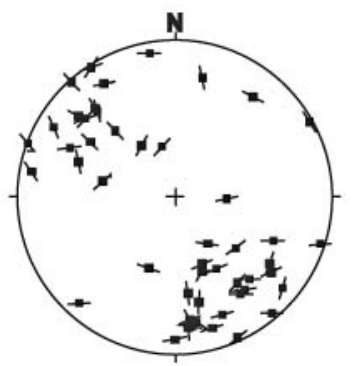

h. $\mathrm{N}=52$

Fig. 7. Structures in the vicinity of the Hitra-Snåsa Fault of the Møre-Trøndelag Fault Complex. (a) Top-to-the-NW reverse fault rooted in, or cut by, the NE-SW-trending Jektvika fault. Shortening in the 'Old Red' clearly intensifies in the direction of strands of the Møre-Trøndelag Fault Complex. Field of view is c. $3 \mathrm{~m}$. (b) Simplified line drawing of relationships between subhorizontal thrust faults and subordinate, normal faults, tension gashes and NWSE-trending strike-slip faults that form a kinematically consistent, epidote-mineralized network in the southeastern parts of the Austrått Formation. Pockets with epidote-bearing mineralization and epidote breccia (grey in figure) are present along jogs on a number of normal faults, providing indicators of top-to-the-NW transport. (c) Low-angle, top-to-the-NW thrusts cutting steep, multilayered cataclasite sheet associated with the Jektvika fault, except for the youngest and outermost cataclasite. Compass for scale. (d) Simplified representation of relationships presented by the Jektvika fault including thrusting of multilayered breccia sheet, sinistral shears cutting breccias and truncation of the multilayered cataclasite sheet by the main fault plane (see text). The variable thickness of the multilayered cataclasite sheet is due to the combination of thrusting and low-angle cutting of the multilayered cataclasite by the late fault plane. (e) Slip-linear representation of faults with epidote-bearing mineralization, related to top-to-the-NW thrusting, AustråttOttersbo area. (f) Poles to m-plane (contoured) and mean m-plane (great circle, trend $320^{\circ}$ ) for faults in (e). (g) Slip-linear representation of structures obtained from NE-SW-trending faults and lineaments related to the Møre-Trøndelag Fault Complex in the study area. The grouping of sliplines parallel to, and normal to the lineament trends, reflecting the distribution of steep, NE-SW-trending, sinistral strike-slip faults, moderately dipping reverse faults with top-to-the-NW displacements and very steep dip-slip faults should be noted. The latter probably represent late reactivation of the strike-slip faults as normal faults. (h) Slip-linear representation of fault readings in the Borgklintan Fm; a number of faults reflect the pattern in (f), and are related to smaller-scale strike-slip faults and thrusts. A number of NE-SW-trending, moderately dipping oblique- and strike-slip faults tentatively represent normal faults that were rotated out of their original orientation during folding of the Borgklintan Formation; such rotations have been described previously from synsedimentary faults in the Devonian of western Norway (Osmundsen et al. 1998).

Central Norway basement window to shallow crustal levels and, eventually, across the ductile-brittle transition.

The c. 401-403 Ma U-Pb titanite ages reported by Bingen et al. (2003, 2005, Fig. 9) provide a lower bracket for top-to-the-
SW retrograde shearing in the Høybakken detachment zone (Bingen et al. 2005). ${ }^{40} \mathrm{Ar} /{ }^{39} \mathrm{Ar}$ hornblende and mica ages from the Central Norway basement window (Dallmeyer et al. 1992; Kendrick et al. 2004), in combination with $\mathrm{U}-\mathrm{Pb}$ ages on titanite 


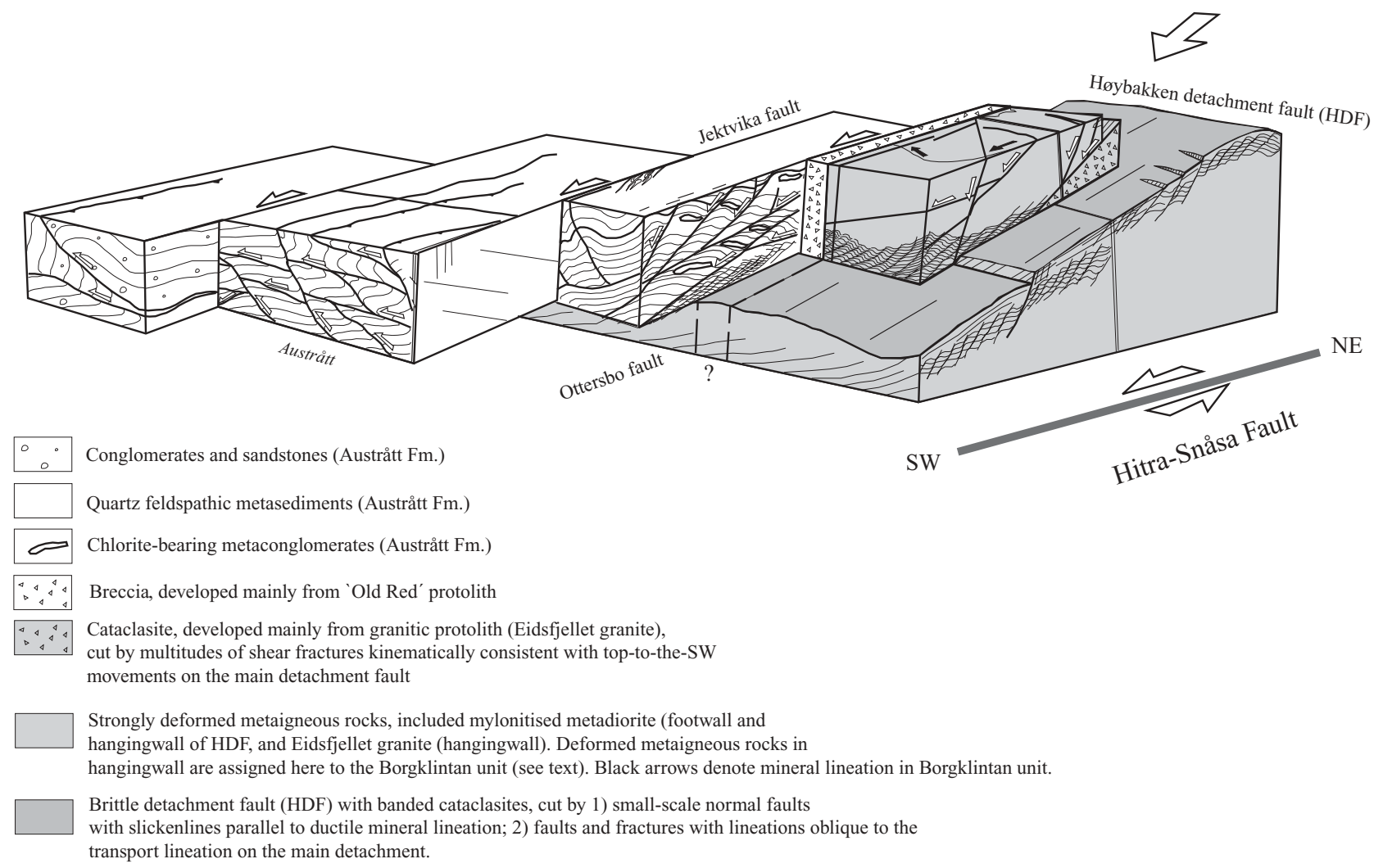

Fig. 8. Schematic block diagram showing relationships between structural elements observed in the hanging wall of the Høybakken detachment fault in the Høybakken-Austrått area. The relationships between the Høybakken detachment fault and the NE-SW-trending faults of the Møre-Trøndelag Fault Complex are not exposed in each case, but it is clear that a number of NE-SW-trending strike-slip faults cut the Høybakken detachment fault or fault products related to the Høybakken detachment fault.

(Bingen et al. 2003; Tucker et al. 2004) are consistent with cooling together with the northern Western Gneiss Region between c. 405 and c. 390-395 Ma (Fig. 9). The older parts of this age interval probably date the amphibolite-facies constrictional strain conditions responsible for the formation of strongly prolate fabrics in the feldspar-rich rocks. In the detachment mylonites, and structurally highest parts of the Central Norway basement window, ${ }^{40} \mathrm{Ar} /{ }^{39} \mathrm{Ar}$ ages of $c$. $386-387 \mathrm{Ma}$ for hornblende, 381-385 Ma for white mica and biotite and 371-356 Ma for K-feldspar (Fig. 9) have been interpreted to represent the progressive cooling of the footwall mylonites from $c .450-550^{\circ}$ to c. $250{ }^{\circ} \mathrm{C}$ over a period of c. $25-30 \mathrm{Ma}$ (Eide et al. 2003; Kendrick et al. 2004). Thus, it appears that exhumation of the rocks in the window from amphibolite-facies conditions at $c$. $390 \mathrm{Ma}$ into the frictional-elastic regime at c. 370-356 Ma occurred at rates of $<1 \mathrm{~mm} \mathrm{a}^{-1}$. A similar conclusion of slow exhumation rates after $c .390 \mathrm{Ma}$ for the northern Western Gneiss Region was reached by Terry et al. (2000) and Terry \& Robinson (2004).

In the outer Trondheimsfjord area, it has been demonstrated that whereas Ordovician igneous titanites are little reset in the rocks of the Støren Nappe of the Upper Allochthon, titanites from the adjacent Western Gneiss Region were completely reset at $395 \pm 2 \mathrm{Ma}$ (Tucker et al. 2004). Thus, it appears that south of the Hitra-Snåsa Fault, the folded contact between the Western Gneiss Region and the rocks of the Støren Nappe of the Upper Allochthon represents a major tectonic boundary characterized by cooling of the footwall through $c$. $550^{\circ}$ at around $395 \mathrm{Ma}$
(Solli et al. 1997; Robinson et al. 2004; Tucker et al. 2004). Adjacent to the contact, the structure of the footwall is dominated by folded, top-to-the-SW and sinistral shear indicators, and the contact has recently been interpreted in terms of an early, ductile extensional detachment (Agdenes detachment of Robinson et al. 2004). The implication for the study area would be that the highly sheared supracrustals in the southwestern Central Norway basement window are sandwiched between the Agdenes detachment and the younger Høybakken detachment zone (see also Robinson et al. 2004). Thus, the gneissic core of the Central Norway basement window probably shared parts of its exhumation history of NE-SW stretching and top-to-the-SW ductile shearing with a large region, notably the northern Western Gneiss Region and correlative rocks in the Trondheim area south of the Hitra-Snåsa Fault.

\section{Decapitation of the detachment mylonites}

The mineral assemblages in the mylonitic, meta-igneous rocks in the hanging wall of the Høybakken detachment fault (Borgklin$\tan$ unit) are largely similar to those observed in the upper parts of the footwall at Høybakken. The flattening of pebbles and development of a low-grade, phyllonitic fabric at Ottersbo is consistent with greenschist-facies, SW-directed tectonic transport and NW-SE-oriented shortening, similar to that observed in the upper parts of the footwall. We suggest that the present brittle detachment fault overprints a low-grade, ductile detachment zone that included the upper parts of the footwall and structurally low 


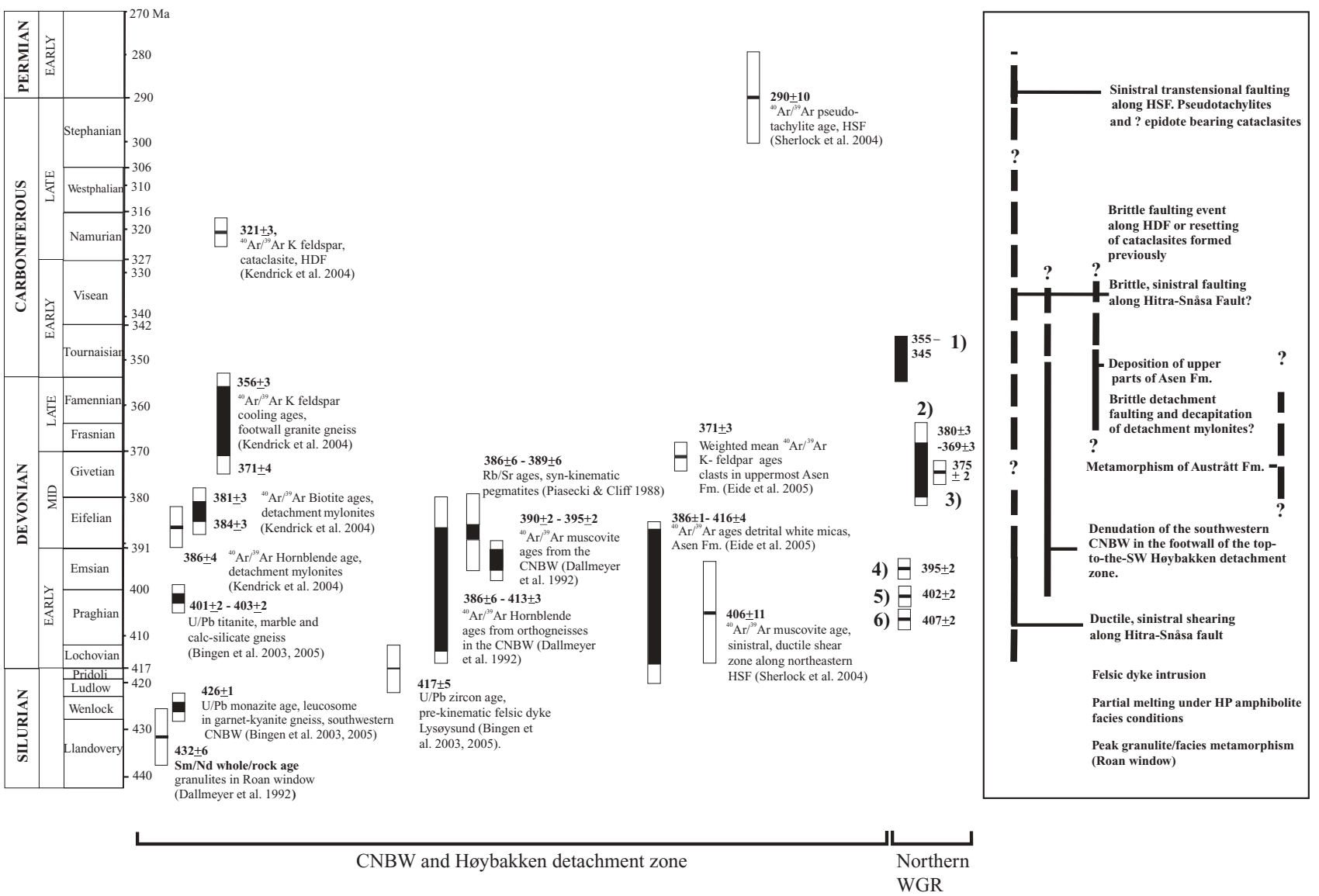

Fig. 9. Summary of radiometric ages from the study area and from the northern Western Gneiss Region discussed in the text and interpretation of geological events. Ages from the northern Western Gneiss Region are as follows. (1) Range of ${ }^{40} \mathrm{Ar}{ }^{39} \mathrm{Ar}$ K-felspar ages reported by Root et al. (2005) from ultrahigh-pressure domains of the northern Western Gneiss Region. (2) Range of muscovite ages from ultrahigh-pressure domains of the Western Gneiss Region (Root et al. 2005). The young muscovite and K-feldspar ages indicate folding of the northern Western Gneiss Region after $c$. $335 \mathrm{Ma}$ (Root et al. 2005). (3) $\mathrm{U} / \mathrm{Pb}$ monazite age from ductile, sinistral shear zone in the Western Gneiss Region (Terry et al. 2000). (4) U/Pb titanite age from the northern Western Gneiss Region adjacent to the Agdenes detachment (Tucker et al. 2004). (5) U/Pb zircon age of the ultrahigh-pressure Ulsteinvik eclogite (Tucker et al. 2004). (6) U/Pb monazite mean age obtained from eclogite in the northern Western Gneiss Region by Terry et al. (2000). (See text for discussion.)

parts of the present-day hanging wall. The preservation of a sliver of detachment mylonites in the hanging wall of the detachment fault can be explained by brittle truncation of extension-parallel folds (Fig. 10). Truncation of a folded detachment by a younger one has been suggested previously for the Simplon-Brenner fault system in the Eastern Alps (Mantkelow \& Pavlis 1994) and for the Devonian Nordfjord-Sogn detachment in SW Norway (Krabbendam \& Dewey 1998; Osmundsen et al. 1998; Erambert \& Braathen 2005).

The timing of the truncation of the folded detachment mylonites by the Høybakken detachment fault is bracketed by the c. $381-385 \mathrm{Ma},{ }^{40} \mathrm{Ar} /{ }^{39} \mathrm{Ar}$ mica crystallization ages from the detachment mylonites and the c. $320 \mathrm{Ma}{ }^{40} \mathrm{Ar} /{ }^{39} \mathrm{Ar} \mathrm{K}$ feldspar age reported by Kendrick et al. (2004) from the pink cataclasite in the hanging wall of the brittle detachment fault. However, the footwall had probably entered the frictionalelastic regime at around $c .356-370 \mathrm{Ma}$, as suggested by the ${ }^{40} \mathrm{Ar} /{ }^{39} \mathrm{Ar} \mathrm{K}$-feldspar cooling ages (Kendrick et al. 2004). This suggests that decapitation of the footwall by the brittle detachment fault may have taken place closer to $370 \mathrm{Ma}$ than to $320 \mathrm{Ma}$. The kinematics of swarms of brittle faults that crosscut the pink cataclasite associated with the Høybakken detach- ment fault (Fig. 5c and d), show that top-to-the-SW movements still prevailed at this stage.

\section{Brittle detachment faulting, late-stage exhumation and 'Old Red' sedimentation}

The propagation of the Høybakken detachment fault into the exposed structural level may also be reflected by the adjacent 'Old Red' stratigraphy. The upper parts of the 'Old Red' at Asenøy experienced pressures and temperatures not much above diagenetic conditions (Eide et al. 2003). In the uppermost parts of the Asenøy basin, clast petrography and palaeocurrent data from coarse alluvial deposits indicate east to west sediment transport (Haabesland et al. 2002). An ${ }^{40} \mathrm{Ar} /{ }^{39} \mathrm{Ar} \mathrm{K}$-feldspar age of $372 \pm 3 \mathrm{Ma}$ obtained from a gneiss clast at high stratigraphic levels in the Asenøy Basin confirms the link between high levels of the 'Old Red' stratigraphy and source areas in the Central Norway basement window (Eide et al. 2003, 2005). The highest stratigraphic levels of the 'Old Red' succession must be Late Devonian or younger in age to allow exhumation from depths corresponding to $250{ }^{\circ} \mathrm{C}$ to the palaeosurface prior to erosion and deposition (Eide et al. 2003). Thus, the above age constraints are 


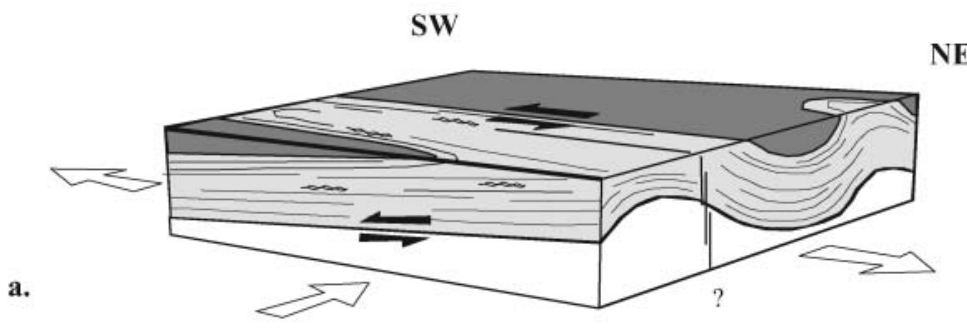

NE

$402 \mathrm{Ma}$

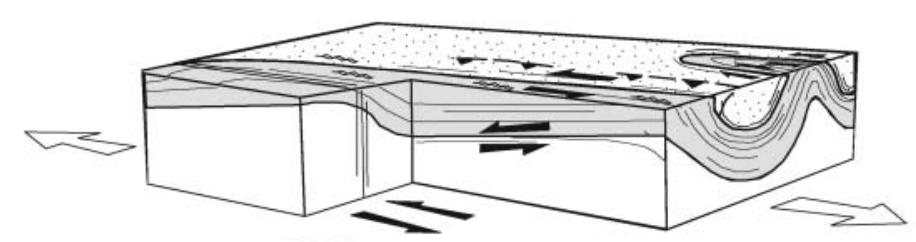

$395 \mathrm{Ma}$

b.
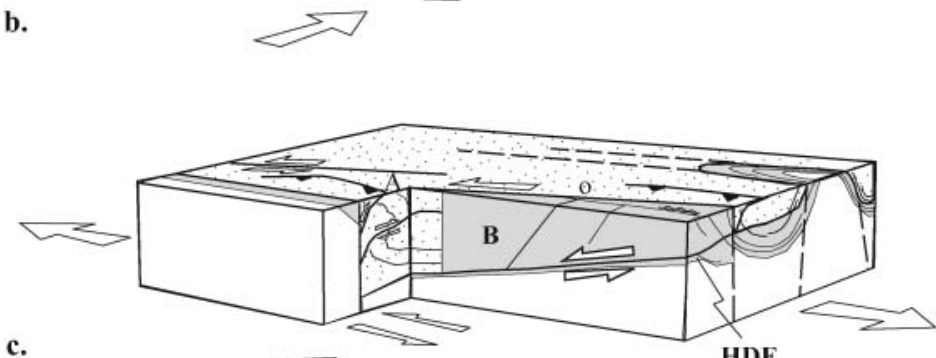

c.

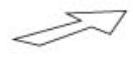

HDF

$370 \mathrm{Ma}$

$380 \mathrm{Ma}$

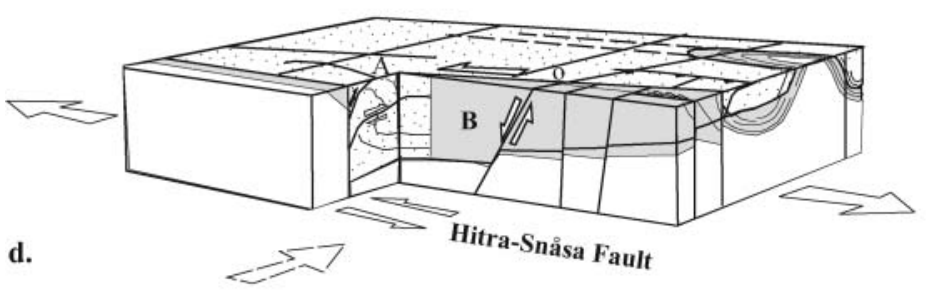

\section{CNBW/WGR}

Rocks of the Upper Allochthon, strongly sheared in ductile detachment zone

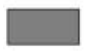

Rocks of the Upper and uppermost Allochthons, unaffected by ductile extension

'Old Red' sedimentary rocks

$\mathrm{A}=$ Austrått Formation; $\mathrm{B}=$ Borgklintan unit; $\mathrm{O}=$ Ottersbo fault

Fig. 10. Schematic illustration of relationships between detachment mylonites, the Høybakken detachment fault, the Borgklintan unit and the 'Old Red' Bjugn Basin as discussed in the text. Schematic, non-linear time scale based on benchmark radiometric ages referred to in text. Top of model corresponds roughly to present-day exposed structural level and not to the palaeosurface. (a) Top-to-the-SW movement along a regional, extensional shear zone accommodating denudation of the Central Norway basement window (CNBW) and the northern Western Gneiss Region (WGR) in a constrictional strain field. The older parts of the 'Old Red' may have been deposited at the surface (above the model) at this time, on rocks of the Upper and Uppermost Allochthons. (b) Continued top-to-the-SW movements along the detachment zone; constriction led to folding of the entire crustal section, including the Central Norway basement window, the detachment zone and the 'Old Red' basin. Continued burial of the 'Old Red' deposits and contraction of geotherms related to extensional detachment faulting led to very low-grade and low-grade metamorphism of the 'Old Red', increasing in the direction of the contact with the hotter footwall rocks. Shearing along this contact was dextral along SE-dipping fold flanks and sinistral along NW-dipping ones, as suggested by Séranne (1992). Low-grade phyllonitic fabrics formed in the hanging-wall rocks along the contact. As the (at present exposed) levels of the Austrått Fm would have been located close to the brittle-ductile transition at this stage, brittle fractures may well have developed that trapped fluids and allowed minerals such as epidote to precipitate. Some of the brittle, epidote-bearing structures in the study area may have started to form in this interval. (c) Brittle detachment fault (Høybakken detachment fault; HDF) truncates previous fabrics in the ductile detachment zone. As a result, part of the folded detachment mylonite was captured in the hanging wall of the Høybakken detachment fault as the Borgklintan unit (B). The rocks of the Central Norway basement window underwent denudation under conditions where $T$ was below $c .250{ }^{\circ} \mathrm{C}$. In the 'Old Red', networks of quartz-epidote-mineralized fracture networks form adjacent to the Høybakken detachment fault. The Ottersbo fault $(\mathrm{O})$ may have started forming at this stage, incising the flank of the decapitated fold limb at present represented by the Borgklintan unit. In the Austrått Formation (A), shortening by thrusting intensified adjacent to strands of the MøreTrøndelag Fault Complex that developed as parallel and Reidel shears along the Hitra-Snåsa Fault. At the surface, the Asen Fm was probably being 
consistent with the brittle detachment fault controlling late-stage sedimentation in the Late Devonian or Early to Mid-Carboniferous (Eide et al. 2005).

The significance of Late Devonian and/or younger slip along the Høybakken detachment fault is probably best illustrated by the late stages of exhumation of the Central Norway basement window. Assuming a geothermal gradient of $25^{\circ} \mathrm{C} \mathrm{km}^{-1}$, some $8-10 \mathrm{~km}$ of exhumation would be required to expose rocks with preserved c. $370 \mathrm{Ma}{ }^{40} \mathrm{Ar} /{ }^{39} \mathrm{Ar}$ feldspar cooling ages at the surface during deposition of the uppermost 'Old Red' (Eide et al. 2005). Contraction of geotherms in relation with detachment faulting may significantly reduce this number, but the relatively slow exhumation rates since $c .390 \mathrm{Ma}$ indicate that geotherm contraction may have been limited compared with the Early and early Mid-Devonian. Even with an unrealistic geotherm of $50{ }^{\circ} \mathrm{C} \mathrm{km}^{-1}$, post-370 Ma exhumation from a depth of $4-6 \mathrm{~km}$ would be required. The associated slip on the low-angle Høybakken detachment fault could then easily have been of the order of $10 \mathrm{~km}$ or more. Significant slip events may have occurred as late as $c$. $320 \mathrm{Ma}$ (Kendrick et al. 2004), and the banded cataclasites and ultracataclasites at the base of the hanging wall in Høybakken could be even younger. In SW Norway, the Nordfjord-Sogn detachment was reactivated in the Permian and in the Late Jurassic-Early Cretaceous (Torsvik et al. 1992; Eide et al. 1997).

\section{Brittle extension, contraction and the role of the Møre- Trøndelag Fault Complex}

In the study area, normal faults are consistent with NE-SW horizontal extension and vertical shortening, whereas brittle thrusts and reverse faults indicate NW-SE shortening. If these structures are treated as roughly contemporaneous in view of the common epidote-bearing mineralization, the resulting strain field would correspond to general constriction $(1<k<\infty$ in the Flinn (1962) plot). The formation of the epidote-bearing brittle structures appears to partly predate and partly post-date the brittle detachment fault at Høybakken, and certainly post-dates deposition of the Austrått Formation. Thus, these structures probably did not develop exclusively as intra-hanging-wall structures coeval with ductile shearing in the footwall, but appear to have continued to accompany the deactivation of the brittle detachment as a major, top-to-the-SW normal fault.

The Hitra-Snåsa Fault of the Møre-Trøndelag Fault Complex is situated in a steep, kilometre-wide mylonite belt that shows abundant evidence for ductile, sinistral displacements (Grønlie \& Roberts 1989; Grønlie et al. 1991; Roberts 1998; Watts 2001). Sinistral shearing along the Møre-Trøndelag Fault Complex could have been roughly contemporaneous with denudation of the Central Norway basement window in the footwall of the HDZ, as suggested by Séranne (1992), and probably of Early to Mid-Devonian age. Supporting this model is an ${ }^{40} \mathrm{Ar} /{ }^{39} \mathrm{Ar}$ white mica age of $406 \pm 11 \mathrm{Ma}$ reported from the mylonites of the Møre-Trøndelag Fault Complex by Sherlock et al. (2004).

After ductile shearing, localization of strains led to formation of brittle faults of regional importance. Green, epidote-veined cataclasites from the core of the Hitra-Snåsa Fault have been interpreted to record the earliest post-mylonitic, sinistral faulting events, occurring under prehnite-pumpellyite- to lower greenschist-facies conditions (Grønlie et al. 1991; Watts 2001). The broad similarity in fault products and faulting conditions (saussuritization, epidote mineralization, cataclasis) suggests a link between a main phase of brittle, sinistral faulting along the Møre-Trøndelag Fault Complex and the development of epidotemineralized structures in the study area. Top-to-the-NW thrusting in the Austratt Formation, close to the strands of the MøreTrøndelag Fault Complex, appears to have alternated with sinistral strike-slip along the Hitra-Snåsa Fault. Considering the high angle between the thrust direction and the strike-slip faults as well as the regional evidence, we suggest that the thrusts of the Austrått Formation represent the brittle kinematic equivalents of the NE-SW-trending folds and thrusts that deform the northern Western Gneiss Region, the Central Norway basement window including the detachment mylonites and the 'Old Red' deposits. We interpret this as evidence for constriction to have prevailed as the rocks of the study area passed into the brittle regime. The thrusting in the Austrått Formation probably took place during or after metamorphism of the Austrått Formation, and during the juxtaposition with the Borgklintan unit. Shortening by SE-verging folds in the 'Old Red' farther SW in the outer Trondheim region and in the Devonian basins of SW Norway has been suggested to be Mid-Devonian to Late Devonian-Early Carboniferous in age based on stratigraphic evidence and palaeomagnetic dating (Torsvik et al. 1986, 1989; Chauvet \& Séranne 1994; Osmundsen \& Andersen 2001). The late, NW-SE-trending lineations on the Høybakken detachment fault are statistically parallel to those of the thrusts and reverse faults, and may possibly also be related to the latest phase of top-to-the-NW thrusting.

In the study area, the curving into the Jektvika fault of some reverse faults resembles the pattern associated with positive flower or 'palm-tree' structures, described from other areas of strike-slip faulting such as the San Andreas Fault of the southwestern USA (e.g. Sylvester 1988). In transtension, the area of resolved strike-slip faulting is also the area represented by the highest transtensional angles and the most intense extensionnormal shortening (Krabbendam \& Dewey 1998; Dewey 2002). Thus, flower structures should be expected to form along strikeslip faults that develop in transtension. Considering the long movement history of the Møre-Trøndelag Fault Complex, structural geometries resembling 'flower structures' may have developed along the fault complex from the Early Devonian into the late Devonian-Early Carboniferous, at different crustal levels and thus under different rheological conditions.

Despite the differences in crustal level and, probably, timing, the trend of the thrust transport lineation observed by us in the Austrått Formation $\left(c .320-140^{\circ}\right)$, is remarkably similar to that associated with SE-directed, eclogite-facies thrusting in the northern Western Gneiss Region in the interval c. 407-395 Ma (Terry \& Robinson 2004). This time interval was associated with very high exhumation rates, probably owing to combination of thrusting with high-level extension (Terry \& Robinson 2004), and overlaps with the ${ }^{40} \mathrm{Ar} /$

${ }^{39} \mathrm{Ar}$ age of ductile sinistral shearing $(406 \pm 11 \mathrm{Ma}$, Sherlock et al.

deposited in this time interval (Eide et al. 2005). NW-SE-trending shortening continued, as the late Devonian or younger Asen Fm was gently folded after its deposition. (d) Together with the Austrått Fm, the Borgklintan unit underwent further extension and strike-slip deformation along faults associated with cataclasis and epidote-bearing mineralization. Extension-normal shortening was now probably minor. Epidote-mineralized oblique, normal and strikeslip faults demonstrably cut deformation products associated with the Høybakken detachment fault, such as the pink cataclasite developed from the Eidsfjellet granite that yielded the c. 320 Ma K-feldspar age reported by Kendrick et al. (2004). This deformation may be related to the Late Carboniferous-Early Permian movements along the Hitra-Snåsa Fault recorded by Watts (2001) and Sherlock et al. (2004). 
2004) along the Hitra-Snåsa Fault. Thus it appears that a principal trend of shortening remained at right angles to the MøreTrøndelag Fault Complex from the Early Devonian and at least into Mid- and Late Devonian time.

Displacement of the Høybakken detachment fault by subvertical, NE-SW-trending fault strands provides evidence that movements on the Møre-Trøndelag Fault Complex continued in concert with, or after, brittle detachment faulting. Grønlie et al. (1991) and Roberts (1998) considered the green cataclasites and epidote mineralizations along the Møre-Trøndelag Fault Complex to be Late Devonian in age, consistent with a Late Devonian $\mathrm{U}-\mathrm{Pb}$ age obtained from titanite growing in fault-related epidote mineralizations in North-Central Norway (Larsen et al. 2002). A Late Carboniferous-Early Permian ${ }^{40} \mathrm{Ar} /{ }^{39} \mathrm{Ar}$ age of $290 \pm$ $10 \mathrm{Ma}$ obtained from a pseudotachylite inside the epidotebearing cataclasite on the Hitra-Snåsa Fault (Sherlock et al. 2004) inspired the conclusion by Watts (2001) that all the brittle deformation along the Hitra-Snåsa Fault was Permian or younger in age. We prefer a scenario where brittle deformation along the Hitra-Snåsa Fault was initiated in the Devonian to Carboniferous, as part of the regional low-temperature denudation history. It is clear, however, that a number of strike-slip and oblique normal faults cut the Høybakken detachment fault. Some of the latter have slip-lines that plunge in a westerly or northwesterly direction. It is quite probable that these structures correlate with the Late Carboniferous-Early Permian slip event recorded by Watts (2001).

The time interval suggested for transtensional deformation in the Caledonides considered by Dewey \& Strachan (2003) was 410-390 Ma, based on evidence from the North Atlantic region, but in particular from the British Isles and Norway. Based on palaeomagnetic results and ${ }^{40} \mathrm{Ar} /{ }^{39} \mathrm{Ar}$ geochronology, it has been suggested that folding of the Western Gneiss Region around east-west-trending axes, related to transtension by Krabbendam \& Dewey (1998), continued at least into the Early Carboniferous (Torsvik et al. 1986, 1989) and Mid-Carboniferous (Hacker et al. 2003; Root et al. 2005). In combination with the evidence presented above, this allows for extensional detachment shearing and faulting, 'Old Red' sedimentation and NW-SE compression to have continued at least into the Late Devonian-Early Carboniferous. Thus, the upper age bracket placed on Palaeozoic transtension in the North Atlantic domain by Dewey \& Strachan (2003) should probably be shifted by at least 20 Ma towards the younger end of the time scale for the Norwegian domain.

The major frontal thrusts of the Scandinavian thrust stack were not cut by the Møre-Trøndelag Fault Complex. The ductile-tobrittle strains described in this paper were relayed farther inland where top-to-the-SW normal or oblique shearing and faulting was localized along the western margins of the gneiss-cored culminations that straddle the watershed between Norway and Sweden (Fig. 1; Rykkelid \& Andresen 1994; Braathen et al. 2002; Osmundsen et al. 2003). ${ }^{40} \mathrm{Ar} /{ }^{39} \mathrm{Ar}$ geochronology performed on a ductile-to-brittle extensional shear zone that bounds the western margin of the Rombak window (Fig. 1) provided ages in the range from c. 370 to $355 \mathrm{Ma}$ (Coates et al. 1999), which is well in accordance with the younger ages of faulting and 'Old Red' sedimentation proposed by Eide et al. (2003, 2005).

Movements on the Høybakken detachment fault were probably terminated by the cross-cutting of the steep, NW-SE-trending faults that also affect the Central Norway basement window. We suggest that the earliest movements on the steep, NE-SWtrending structures, characterized by epidote-veined green cataclasites, were related to the Devonian to Carboniferous strain field, as the fault planes are parallel to the principal shortening trend and normal to the trend of maximum elongation (see also Eliassen 2003). Epidote mineralization gave way to carbonate and zeolite mineralizations that appear to have commenced during NE-SW extension (see above), but that have generally been assigned to later (Mesozoic?) phases of extension (Grønlie et al. 1991; Watts 2001; Braathen et al. 2002).

\section{Conclusions}

Exhumation of the southwestern Central Norway basement window in the footwall of the Høybakken detachment zone took place from the Early Devonian at around c. $400 \mathrm{Ma}$ to Late DevonianEarly Carboniferous time after c. $365 \mathrm{Ma}$; that is, over a period of more than $30 \mathrm{Ma}$. This is reflected by the age range of the 'Old Red' sedimentary successions deposited in the hanging wall.

Parts of the ductile deformation in the footwall of the Høybakken detachment fault probably developed together with the regional Agdenes detachment of Robinson et al. (2004) and other large-magnitude extensional shear zones in the region, such as the Nesna shear zone (Eide et al. 2002; Osmundsen et al. 2003) and the Nordfjord-Sogn detachment zone (Séranne 1992). Deformation took place in a constrictional strain field, resulting in the formation of extension-parallel folds through the entire structural section. As this section was exhumed past the ductilebrittle transition, the brittle Høybakken detachment fault truncated the folded detachment mylonites, capturing a mylonitic sliver in its hanging wall.

After c. 370-365 Ma, movements on the Høybakken detachment fault were significant enough to exhume the rocks of the Central Norway basement window from a depth corresponding to $c .250{ }^{\circ} \mathrm{C}$ to the surface, where they were eroded and provided detritus to the uppermost parts of the Asenøy Basin. The magnitude of slip accommodated by the low-angle detachment fault in this time interval is thus likely to have been of the order of several kilometres. Significant, top-to-the-SW faulting events along the detachment fault may have occurred as late as $320 \mathrm{Ma}$ (Kendrick et al. 2004), and the banded cataclasites and ultracataclasites at the base of the hanging wall may have formed at an even later stage.

The metamorphic grade of the Austraitt Formation in the vicinity of the Høybakken detachment fault, as well as along the contact with the Borgklintan unit, may be related to contraction of geotherms and juxtaposition of the sedimentary rocks with the hot footwall of the detachment zone, as suggested previously for the 'Old Red' basins in SW Norway (Krabbendam \& Dewey 1998). Strongly reduced exhumation rates after c. 390 Ma would be consistent with the non-metamorphic character of the Late Devonian or younger 'Old Red' succession of the Asenøy area.

The Møre-Trøndelag Fault Complex developed as a sinistral shear zone in the Early or early Mid-Devonian, resolving the sinistral component of deformation in an overall transtensional strain field (Krabbendam \& Dewey 1998; Osmundsen et al. 1998). During or after the low-grade metamorphism of the Austrått Formation, probably in the Mid-Late Devonian and onwards, brittle thrusting at right angles to, and away from, the Hitra-Snåsa Fault intensified along the strike-slip fault strands. Kinematically, the thrusts represent brittle analogues to the extension-parallel folds, and may have formed as parts of positive flower structures that formed along the Møre-Trøndelag Fault Complex. Probably, a constrictional strain field, associated with regional transtension, persisted at least into the late Devonian-Early Carboniferous.

We thank Norsk AGIP, BP Norway, ChevronTexaco, ConocoPhillips, ExxonMobil, Norsk Hydro, Norske Shell, Statoil and the Geological 
Survey of Norway for financial support under the umbrella of the BAT project. We thank P. Robinson for stimulating discussions on the geology of western and Mid-Norway. R. Holdsworth and M. Krabbendam are thanked for constructive reviews.

\section{References}

Alexandrowski, P. 1985. Graphical determination of principal stress direction for slickenside lineation populations: an attempt to modify Arthaud's method. Journal of Structural Geology, 7, 73-82.

Allen, K.C. 1976. Devonian spores from outer Trøndelag. Norsk Geologisk Tidsskrift, 56, 437-448.

Andersen, T.B. \& JAMTVEIT, B. 1990. Uplift of deep crust during orogenic extensional collapse: a model based on field studies in the Sogn-Sunnfjord area of Western Norway. Tectonics, 9, 1097-1111.

Andersen, T.B., Osmundsen, P.T. \& Jolivet, L. 1994. Deep crustal fabrics and a model for the extensional collapse of the southwest Norwegian Caledonides. Journal of Structural Geology, 16, 1191-1203.

Askvik, H. \& Rokoengen, A. 1985. Kristiansund. Geological map of Norway, 1:250 000 series. Geological Survey of Norway, Trondheim.

BERgFJoRd, E. 1989. Den strukturelle utvikling $i$ den devonske Fosen-gruppen og dens underlag, Ørlandet, Sør-Trøndelag. Cand.Scient thesis, University of Bergen.

BERING, D. 1992. The orientation of minor fault plane striae and the associated deviatoric stress tensor as a key to the fault geometry in part of the MoreTrondelag fault zone, on-shore central Norway. In: LARSEN, R.M., BreKKe, H., Larsen, B.T. \& Talleraas, E. (eds) Structural and Tectonic Modelling and its Application to Petroleum Geology. Norwegian Petroleum Society (NPF), Special Publications, 1, 83-90.

Bingen, B., Davis, W.J., Hamilton, M.A., Osmundsen, P.T. \& Nordgulen, $\varnothing$. 2003. $\mathrm{U}-\mathrm{Pb}$ geochronology of metamorphism in Mid-Norway, and implications for the duration of the Scandian orogenic phase in the Scandinavian Caledonides (abstract). In: EIDE, E.A. (ed.) The Alice Wain Memorial Western Norway Eclogite Field Symposium, Abstract Volume. NGU Report, 2003.055, $17-18$

Bingen, B., Austrheim, H., Whitehouse, M.J. \& Davis, W.J. 2004. Trace element signature and $\mathrm{U}-\mathrm{Pb}$ geochronology of eclogite-facies zircon, bergen Arcs, Caledonides of Norway. Contributions to Mineralogy and Petrology, 147, 671-683.

Bingen, B., Davis, W.J. \& Osmundsen, P.T. 2005. Titanite and monazite U-Pb dating of high-grade metamorphism and extensional denudation in the midScandinavian Caledonides. Geochimica et Cosmochimica Acta, 69(10S), A27.

Bratithen, A., Nordgulen, Ø., Osmundsen, P.T., Andersen, T.B., Solli, A. \& Roberts, D. 2000. Devonian, orogen-parallel, opposed extension in the Central Norwegian Caledonides. Geology, 28, 615-618.

Bratithen, A., Osmundsen, P.T., Nordgulen, Ø., Roberts, D. \& Meyer, G. 2002. Orogen-parallel extension of the Caledonides in northern Central Norway: an overview. Norwegian Journal of Geology, 82, 225-241.

BRYHNI, I. 1974. Old Red sandstone of Hustadvika and an occurrence of dolomite at Flatskjer, Nordmøre. Norges Geologiske Undersøkelse, Bulletin, 311, 49-64.

BøE, R. 1989. A pre-Devonian pediment in the lowermost Old Red Sandstone Hitra Group, western Norway. Norsk Geologisk Tidsskrift, 69, 21-28.

$\mathrm{B} \emptyset \mathrm{E}$, R. 1991. Structure and seismic stratigraphy of the innermost mid-Norwegian shelf-an example from the Frohavet area. Marine and Petroleum Geology, 8 , $140-151$.

BøE, R. \& BJerkLie, K. 1989. Mesozoic sedimentary rocks in Edøyfjorden and Beitstadfjorden, central Norway: implications for the structural history of the Møre-Trøndelag Fault Zone. Marine Geology, 87, 287-289.

BøE, R., Atakan, K. \& Sturt, B.A. 1989. The style of deformation in the Devonian rocks on Hitra and Smøla, central Norway. Norges Geologiske Undersøkelse, Bulletin, 414, 1-19.

Chauvet, A. \& Séranne, M. 1994. : Extension-parallel folding in the Scandinavian Caledonides: implications for late-orogenic processes. Tectonophysics, 238, 31-54.

Coates, B.H., Zeltner, D.L., Carter, B.T., Steltenpohl, M.G., Andresen, A. \& KUNK, M.J. 1999. ${ }^{40} \mathrm{Ar} /{ }^{39} \mathrm{Ar}$ and structural investigations of extensional development of the North-Central Norwegian margin. Geological Society of America, Abstracts with Programs, 31(7), 118.

Dallmeyer, R.D., Johansson, L. \& Møller, C. 1992. Chronology of highpressure grqanulite-facies metamorphism, uplift, and deformation within the northern parts of the Western Gneiss region, Norway. Geological Society of America Bulletin, 104, 444-455.

Dewey, J.F. 2002. Transtension in arcs and orogens. International Geology Review, 44, 402-439.

Dewey, J.F. \& Strachan, R. 2003. Changing Silurian-Devonian relative plate motion in the Caledonides; sinistral transpression to sinistral transtension.
Journal of the Geological Society, London, 160, 219-229.

Dobrzhinetskaya, L.F., Eide, E.A., Larsen, R.B., Sturt, B.A., Trønnes, R.G., TAYlor, W.R. \& Posukhova, T.V. 1995. Microdiamonds in high-grade metamorphic rocks from the Western Gneiss Region, Norway. Geology, 23, 597-600.

Eide, E.A., Torsvik, T.H. \& Andersen, T.B. 1997. Ar-Ar geochronologic and paleomagnetic dating of fault breccias; characterization of late Paleozoic and Early Cretaceous fault reactivation in Western Norway. Terra Nova, 9, $135-139$.

Eide, E.A., Osmundsen, P.T., Meyer, G.B. \& Kendrick, M.A. 2002. The Nesna Shear Zone, North-Central Norway: an ${ }^{40} \mathrm{Ar} /{ }^{39} \mathrm{Ar}$ record of Early DevonianEarly Carboniferous ductile extension and unroofing. Norwegian Journal of Geology, 82, 317-339.

Eide, E.A., Haabesland, N.E., Osmundsen, P.T., Kendrick, M.A., Andersen, T.B. \& RoBERTS, D. 2003. ${ }^{40} \mathrm{Ar} /{ }^{39} \mathrm{Ar}$ geochronology and dating of continental sedimentary rocks: late Devonian-Early Carboniferous 'Old Red Sandstone' discovered in outer Trøndelag. Abstracts and Proceedings of the Geological Society of Norway, 1, 21.

Eide, E.A., Haabesland, N.E., Osmundsen, P.T., Andersen, T.B., Roberts, D. \& KendRICK, M.A. 2005. Modern techniques and Old Red problemsdetermining the age of continental sedimentary deposits with ${ }^{40} \mathrm{Ar} /{ }^{39} \mathrm{Ar}$ provenance analysis in west-central Norway. Norwegian Journal of Geology, 85, 133-149.

EliassEn, H.E. 2003. Sen-kaledonske og yngre (mesosoiske og kenosoiske) forkastninger på Frøya, Møre-Trøndelagkysten. Cand.Scient. thesis, University of Bergen.

Erambert, M. \& BraAthen, A. 2005. Structural and metamorphic evolution during exhumation of the Engebøfjellet eclogite, western Gneiss region, Norway. Journal of Metamorphic Petrology, in press.

Fletcher, J.M. \& Bartley, J.M. 1994. Constrictional strain in a noncoaxial shear zone-implications for fold and rock fabric development, central Mojave Core Complex, California. Journal of Structural Geology, 16, 555-570.

FlinN, D. 1962. On folding during three-dimensional progressive deformation. Quarterly Journal of the Geological Society, London, 118, 385-433.

Fossen, H. 1992. The role of extensional tectonics in the Caledonides of southern Norway. Journal of Structural Geology, 14, 1033-1046.

Fossen, H. \& DunLaP, W.J. 1998. Timing and kinematics of Caledonian thrusting and extensional collapse, southern Norway: evidence from ${ }^{40} \mathrm{Ar} /{ }^{39} \mathrm{Ar}$ thermochronology. Journal of Structural Geology, 20, 765-781.

Gabrielsen, R.H., Brathhen, A., Dehls, J. \& Roberts, D. 2002. Tectonic lineaments of Norway. Norwegian Journal of Geology, 82, 153-174.

GEE, D.G. 1975. A tectonic model for the central part of the Scandinavian Caledonides. American Journal of Science, 275, 468-515.

Gilotti, J.A. \& Hull, J.M. 1993. Kinematic stratification in the hinterland of the central Scandinavian Caledonides. Journal of Structural Geology, 15, 629-646.

Grønlie, A. \& Roberts, D. 1989. Resurgent strike-slip duplex development and the Hitra-Snåsa and Verran Faults, Møre-Trøndelag Fault Zone, Central Norway. Journal of Structural Geology, 11, 295-305.

Grønlie, A., Nilsen, B. \& Roberts, D. 1991. Brittle deformation history of fault rocks on the Fosen Peninsula, Trøndelag, Central Norway. Norges Geologiske Undersøkelse Bulletin, 421, 357-393.

Hacker, B., Andersen, T.B., Root, D., Walsh, E., Young, D. \& Mattinson, J. 2003. Exhumation of Norwegian UHP rocks: what's come up? (abstract). In: EIDE, E.A. (ed.) The Alice Wain Memorial Western Norway Eclogite Field Symposium, Abstract Volume. NGU Report, 2003.005, 57-58.

HACKER, B.R. \& GANS, P.B. 2005. Continental collisions and the creation of ultrahigh-pressure terranes: petrology and thermochronology of nappes in the central Scandinavian Caledonides. Geological Society of America Bulletin, 117, doi:10.1130/B25549

HAABESLAND, N.E. 2002. Sedimentarkitektur og migrasjon av faciesenheter ved innfylling av et tektonisk aktivt halvgrabenbasseng, et eksempel fra Asenøy devonbassenget, Fosen, Trøndelag. Cand.Scient thesis, University of Oslo.

Haabesland, N.E., Osmundsen, P.T. \& Andersen, T.B. 2002. Tectono-sedimentary evolution of the Asen formation, in a Devonian half-graben at Fosen, Trøndelag. Abstracts and Proceedings of the Norwegian Geological Society, 2, 100-103.

Hossack, J.R. 1984. The geometry of listric normal faults in the Devonian basins of Sunnfjord, W. Norway. Journal of the Geological Society, London, 141, 629-637.

Jolivet, L., Raimbourg, H., Avigad, D., Labrousse, L., Austrheim, H. \& ANDERSEN, T.B. 2005. Softening triggered by eclogitization, the first step toward exhumation during continental subduction. Earth and Planetary Science Letters, 237, 532-547.

Kendrick, M.A., Eide, E.A., Roberts, D. \& Osmundsen, P.T. 2004. The MidLate Devonian Høybakken Detachment, Central Norway: ${ }^{40} \mathrm{Ar} /{ }^{39} \mathrm{Ar}$ evidence for prolonged late/post Scandian extension and uplift. Geological Magazine, 141, 329-344. 
KrabbendaM, M. \& DeWEY, J.F. 1998. Exhumation of UHP rocks by transtension in the Western Gneiss region, Scandinavian Caledonides. In: Holdsworth, R.E., Strachan, R.A. \& Dewey, J.F. (eds) Continental Transpressional and Transtensional Tectonics. Geological Society, London, Special Publications, 135, 159-181.

Larsen, Ø., Skår, Ø. \& Pedersen, R.-B. 2002. U-Pb zircon and titanite geological constraints on the late/post-Caledonian evolution of the Scandinavian Caledonides in North-Central Norway. Norwegian Journal of Geology, 82, 1-14.

MantKelow, N.S. \& Pavlis, T.L. 1994. Fold-fault-relationships in low-angle detachment systems. Tectonics, 13, 668-685.

MøLleR, C. 1988. Geology and metamorphic evolution of the Roan area, Vestranden, Western Gneiss Region, Central Norwegian Caledonides. Norges Geologiske Undersøkelse, Bulletin, 413, 1-31.

Nordgulen, Ø., Braathen, A., Corfu, F., Osmundsen, P.T. \& Husmo, T. 2002. Polyphase kinematics and geochronology of the late-Caledonian Kollstraumen detachment, north-central Norway. Norwegian Journal of Geology, 82, 299-316.

Norton, M.G. 1986. Late Caledonian extension in western Norway: a response to extreme crustal thickening. Tectonics, 5, 195-204.

Osmundsen, P.T. \& Andersen, T.B. 2001. The Devonian basins of western Norway: products of large-scale sinistral transtension? Tectonophysics, 332, 51-68.

Osmundsen, P.T., Andersen, T.B., Markussen, S. \& Svendby, A.K. 1998. Tectonics and sedimentation in the hanging wall of a regional extensional detachment: the Devonian Kvamshesten basin, W. Norway. Basin Research, 10, 213-234.

Osmundsen, P.T., Braathen, A., Nordgulen, Ø., Roberts, D., Meyer, G.B. \& EIDE, E. 2003. The Devonian Nesna shear zone and adjacent gneiss-cored culminations, North-Central Norwegian Caledonides. Journal of the Geological Society, London, 160, 137-150.

Osmundsen, P.T., Braathen, A. \& Sommaruga, A. et AL. 2005. Metamorphic core complexes and gneiss-cored culminations along the Mid-Norwegian margin: an overview and some current ideas. In: WANDÅs, B., EIDE, E.A. \& Gradstein, F. (eds) Onshore-Offshore Relationships on the Mid-Norwegian Margin. Norwegian Petroleum Society, Special Publications, 12, 29-31.

Piasecki, M.A.J. \& ClifF, R.A. 1988. Rb-Sr dating of strain-induced mineral growth in two ductile shear zones in the Western Gneiss Region of NordTrøndelag, Central Norway. Norges Geologiske Undersøkelse, Bulletin, 413, 33-50.

Redfield, T.F., Osmundsen, P.T. \& Hendriks, B.W.H. 2005. The role of fault reactivation and growth in the uplift of western Fennoscandia. Journal of the Geological Society, London, 162, 1013-1030.

RindstaD, B. \& GrøNlie, A. 1986. Landsat TM-data used in the mapping of large-scale geological structures in coastal areas of Trøndelag, Central Norway. Norges Geologiske Undersøkelse, Bulletin, 407, 1-12.

Roberts, D. 1983. Devonian tectonic deformation in the Scandinavian Caledonides and its regional perspectives. Norges Geologiske Undersøkelse, Bulletin, 380, $85-96$.

Roberts, D. 1998. High-strain zones from meso- to macro-scale at different structural levels, Central Norwegian Caledonides. Journal of Structural Geology, 20, 111-119.

Roberts, D. \& Gale, G.H. 1978. The Caledonian-Appalachian Iapetus Ocean. In: TARLING, G.H. (ed.) Evolution of the Earth's Crust. Academic Press, London, $255-324$.

Roberts, D. \& Gee, D.G. 1985. An introduction to the structure of the Scandinavian Caledonides. In: Gee, D.G. \& SturT, B.A. (eds) The Caledonian Orogen in Scandinavia and Related Areas. Wiley, Chichester, $55-68$.

Robinson, P. 1995. Extension of Trollheimen tectono-stratigraphic sequence in deep synclines near Molde and brattvåg, Western Gneiss Region, southern Norway. Norsk Geologisk Tidsskrift, 75, 181-198.

Robinson, P., Tucker, R.D., Solli, A., M, P., Krogh, T.E., Gee, D.G. \& Nordgulen, Ø. 2004. Scandian thrusting and extension in the Western Gneiss Region, Sør Trøndelag and Møre og Romsdal, Norway (abstract). Geologiska Foreningen i Stockholm, Førhandlingar (GFF), 126(1), 84-85.

Root, D.B., Hacker, B.R., Gans, P.B., Ducea, M.N., Eide, E.A. \& MosenFELDER, J.L. 2005. Discrete ultrahigh-pressure domains in the Western Gneiss region, Norway: implications for formation and exhumation. Journal of Metamorphic Geology, 23, 45-61.

RykKelid, E. \& ANDRESEN, A. 1994. Late Caledonian extension in the Ofoten area, northern Norway. Tectonophysics, 231, 157-169.

SÉranne, M. 1992. Late Palaeozoic kinematics of the Møre-Trøndelag Fault Zone and adjacent areas, Central Norway. Norsk Geologisk Tidsskrift, 72, 141-158.

SÉranne, M. \& SÉguret, M. 1987. The Devonian basins of western Norway: tectonics and kinematics of an extending crust. In: Coward, M.P., Dewey, J.F. \& Hancock, P.L. (eds) Continental Extensional Tectonics. Geological Society, London, Special Publications, 28, 537-548.

Sherlock, S., Watts, L., Holdsworth, R.E. \& Roberts, D. 2004. Dating fault reactivation by $\mathrm{Ar} / \mathrm{Ar}$ laserprobe: an alternative view of apparently cogenetic mylonite-pseudotachylite assemblages. Journal of the Geological Society, London, 161, 335-338.

SiedlecKA, A. 1975. Old Red Sandstone lithostratigraphy and sedimentation of the outer Fosen area, Trondheim region. Norges Geologiske Undersøkelse, Bulletin, 321, 1-35.

Siedlecka, A. \& Siedlecki, S. 1972. A contribution to the geology of the Downtonian sedimentary rocks of Hitra. Norges Geologiske Undersøkelse, Bulletin, 275, 1-28.

Sjöström, H. \& Bergman, S. 1989. Asymmetric extension and Devonian(?) normal faulting; examples from the Caledonides in eastern Trøndelag and western Jämtland (extended abstract). Geologiska Föreningens i Stockholm Förhandlingar, 111, 407-410.

Sommaruga, A. \& Bøe, R. 2002. Geometry and subcrop maps of shallow Jurassic basins along the Mid-Norway coast. Marine and Petroleum Geology, 19, $1029-1042$

SolLI, A. 1995. Berggrunnskart over Nord-Trøndelag og Fosen. Geological Survey of Norway, Trondheim.

Solli, A., Robinson, P. \& Tucker, R.D. 1997. Proterozoic Basement and Scandian Geology of the Outer Trondheimsfjord Region. Geological Survey of Norway, Report, $\mathbf{9 7 . 1 3 3}$

Stephens, M.B. \& Gee, D.G. 1985. A tectonic model for the evolution of the eugeoclinal terranes in the Central Scandinavian Caledonides. In: GeE, D.G. \& Sturt, B.A. (eds) The Caledonide Orogen: Scandinavia and Related Areas. Wiley, Chichester, 953-978.

Sylvester, A.G. 1988. Strike-slip faults. Geological Society of America Bulletin, 100, $1666-1703$.

Terry, M.P. \& Robinson, P. 2003. Evolution of amphibolite-facies structural features and boundary conditions for deformation during exhumation of highand ultrahigh-pressure rocks, Nordøyane Western Gneiss Region, Norway. Tectonics, 22(1036), doi: 10.1029/2001TC001349

Terry, M.P. \& Robinson, P. 2004. Geometry of eclogite-facies structural features: implications for production and exhumation of ultrahigh-pressure and highpressure rocks, Western Gneiss Region, Norway. Tectonics, 23(TC2001), doi:10.1029/2002TC001401.

Terry, M.P., Robinson, P., Hamilton, M.A. \& Jercinovic, M.J. 2000. Monazite geochronology of UHP and HP metamorphism, deformation and exhumation, Nordøyane, Western Gneiss Region, Norway. American Mineralogist, 85, $1651-1664$

Torsvik, T.H., Sturt, B.A., Ramsay, D.M., Kisch, H.J. \& Bering, D. 1986. The tectonic implications of Solundian (Upper Devonian) magnetization of the Devonian rocks of Kvamshesten, western Norway. Earth and Planetary Science Letters, 80, 337-347.

Torsvik, T.H., SturT, B.A. \& Ramsay, D.M. ET AL. 1989. Palaeomagnetic constraints on the early fault history of the Møre-Trøndelag Fault Zone, Central Norway. In: Kissel, C. \& LAJ, C. (eds) Palaeomagnetic Rotations and Continental Deformation. Kluwer Academic, Dordrecht, 431-457.

Torsvik, T.H., Sturt, B.A., Swensson, E., Andersen, T.B. \& Dewey, J.F. 1992. Palaeomagnetic dating of fault rocks: evidence for Permian and Mesozoic movements and brittle deformation along the extensional Dalsfjord fault, western Norway. Geophysical Journal International, 109, $565-580$

Tucker, R.D., Robinson, P. \& Solli, A. et AL. 2004. Thrusting and extension in the Scandian hinterland, Norway: new $\mathrm{U}-\mathrm{Pb}$ ages and tectonostratigraphic evidence. American Journal of Science, 304, 477-532.

WAIN, A. 1997. New evidence for coesite in eclogite and gneisses: defining an ultrahigh-pressure province in the Western Gneiss region of Norway. Geology, 25, 927-930

Watts, L. M. 2001. The Walls Boundary Fault Zone and the Møre-Trøndelag Fault Complex: a case study of two reactivated fault zones. $\mathrm{PhD}$ thesis, University of Durham

WolfF, F.C. 1976. Trondheim. Geological map of Norway, Bedrock map, 1:250 000 series. Geological Survey of Norway, Trondheim. 